\title{
16. MAGNETOSTRATIGRAPHY OF PALEOGENE AND UPPER CRETACEOUS SEDIMENTS FROM BROKEN RIDGE, EASTERN INDIAN OCEAN ${ }^{1}$
}

\author{
Jeff Gee, ${ }^{2}$ Chris T. Klootwijk, ${ }^{3}$ and Guy M. Smith ${ }^{4}$
}

\begin{abstract}
Broken Ridge represents a fragment of the oceanic Kerguelen-Heard platform, constructed at high southern latitudes in the middle Cretaceous and rifted apart during the middle Eocene (43-45 Ma). The approximately $1400-\mathrm{m}$ section of prerift sediments on Broken Ridge preserves a polarity sequence that spans the middle Eocene to Upper Cretaceous (Chrons C18/C20 to C34), including a 500-m continuous sequence from the lower Eocene (C23R) to the Maestrichtian/Campanian boundary (C32R). The polarity record, together with biostratigraphic data, provides a well-constrained time framework for interpreting the history of Broken Ridge. Inclinations in the lower portion of the section are generally $5^{\circ}-10^{\circ}$ shallower than the expected geocentric axial dipole inclination. Comparison of inclination and porosity changes with stratigraphic depth suggests the importance of compaction in generating these shallow inclinations. Changes in the magnetic fabric, reflected in the anisotropy of anhysteretic remanence, provide additional support for this interpretation.
\end{abstract}

\section{INTRODUCTION}

Broken Ridge is a shallow $(1100 \mathrm{~m})$, east-west-trending plateau in the eastern Indian Ocean with a steep southern slope and a more gently inclined northern margin (Fig. 1). Recent drilling results from Ocean Drilling Program (ODP) Legs 119, 120, and 121 (Barron, Larsen, et al., 1989; Schlich, Wise, et al., 1989; Peirce, Weissel, et al., 1989) indicate that Broken Ridge and the Kerguelen Plateau represent conjugate fragments of an oceanic platform constructed by the Kerguelen hot spot (approximately $50^{\circ} \mathrm{S}$ ) during the middle Cretaceous and rifted apart during the middle Eocene (43-45 Ma). Subsequent seafloor spreading has resulted in approximately $20^{\circ}$ of northward displacement of Broken Ridge (e.g., Mutter and Cande, 1983). Broken Ridge is overlain by $>1500 \mathrm{~m}$ of Upper Cretaceous to Pleistocene sediments, which record its prerift sedimentary environment at high southern latitudes and document the rifting/drifting process. The magnetic polarity sequence preserved in these sediments, together with biostratigraphic data, provides a well-constrained time framework in which to interpret the history of Broken Ridge.

The sedimentary sequence on Broken Ridge consists of two major lithologic units: (1) a flat-lying sequence of Neogene and upper Eocene nannofossil oozes that unconformably overlies (2) Upper Cretaceous and Paleogene sediments that dip gently $\left(<2^{\circ}\right)$ toward the north (Fig. 2). The latter unit comprises siliceous and ash-bearing carbonates, cherts, and a basal sequence of glauconite-bearing tuffs. The low sedimentation rate $(<0.5 \mathrm{~cm} / 100 \mathrm{yr})$, poor quality of the whole-core remanence data, and inadequate density of discrete samples preclude establishment of a magnetostratigraphy for the Neogene sediments. The results from lithologic Unit I are not discussed further in this paper. In contrast, the dipping and truncated sequence from Sites 752 and 754 yielded a complete polarity sequence from the lower Eocene to the Maestrichtian/Campanian boundary (Chrons C23R to C32R).

\footnotetext{
${ }^{1}$ Weissel, J., Peirce, J., Taylor, E., Alt, J., et al., 1991. Proc. ODP, Sci. Results, 121: College Station, TX (Ocean Drilling Program).

${ }^{2}$ Scripps Institution of Oceanography, La Jolla, CA 92093, U.S.A.

${ }^{3}$ Bureau of Mineral Resources, Geology and Geophysics, P.O. Box 386, Canberra ACT 2601, Australia.

${ }^{4}$ Dept. Earth and Planetary Sciences, St. Louis University, P.O. Box 8099, Laclede Station, St. Louis, MO 63156, U.S.A.
}

In addition, the upper portion of the Cretaceous normal polarity zone $(\mathrm{C} 34 \mathrm{~N})$ was recovered from Site 755 , and the short middle Eocene section from Site 753 yielded one normal and one reversed polarity interval. The continuity and high mass-accumulation rates (Rea et al., 1990) of this sequence facilitate the comparison of mid- to high-latitude austral fossil assemblages to both the geomagnetic reversal time scale (GRTS) and standard low-latitude zonations (Berggren et al., 1985; Kent and Gradstein, 1985; Bolli et al., 1985).

In addition, the sediments from Broken Ridge afford a unique opportunity to examine the fidelity of inclination data from marine sediments subjected to progressive compaction and diagenesis. Tectonic reconstructions for the Indian Ocean (e.g., Luyendyk and Rennick, 1977: Royer and Sandwell, 1989) together with land-based paleomagnetic studies (e.g., Klootwijk, 1971; Schmidt, 1976) predict little or no latitudinal displacement for Broken Ridge from its formation in the middle Cretaceous until rifting in the middle Eocene. These models suggest that the entire prerift sequence should record a paleolatitude of $47^{\circ}-50^{\circ} \mathrm{S}$, similar to the present location of the Kerguelen hot spot $\left(50^{\circ} \mathrm{S}\right)$. Significant deviations from this expected inclination $\left(65^{\circ}-67^{\circ}\right)$ may cast doubt on the fixity of the Kerguelen hot spot, tectonic models for the Indian Ocean, or the strict validity of the geocentric axial dipole hypothesis. Alternatively, such inclination discrepancies may result from incomplete separation of the primary magnetization or may reflect complications in the preservation of paleolatitudinal information in these sediments.

\section{METHODS}

JOIDES Resolution is equipped with a pass-through cryogenic magnetometer, made by $2 \mathrm{G}$ Enterprises, and alternating field demagnetization coils, automated for the measurement of split cores at spacings of $5 \mathrm{~cm}$ or more. Natural remanent magnetization (NRM) and the remanence after 9-mT demagnetization (the maximum field attainable with the system available during Leg 121 ) were routinely measured at $5-$ or $10-\mathrm{cm}$ spacing for all but the most disturbed sections. All cores from the dipping and truncated sequence on Broken Ridge were well above the practical shipboard sensitivity limit $\left(10^{-9} \mathrm{Am}^{2}\right.$ total moment) of the $2 \mathrm{G}$ magnetometer. The whole-core data have not been deconvolved. Rather, declination and inclination have been calculated by normalizing the moment of the three axes by their respective sensor 


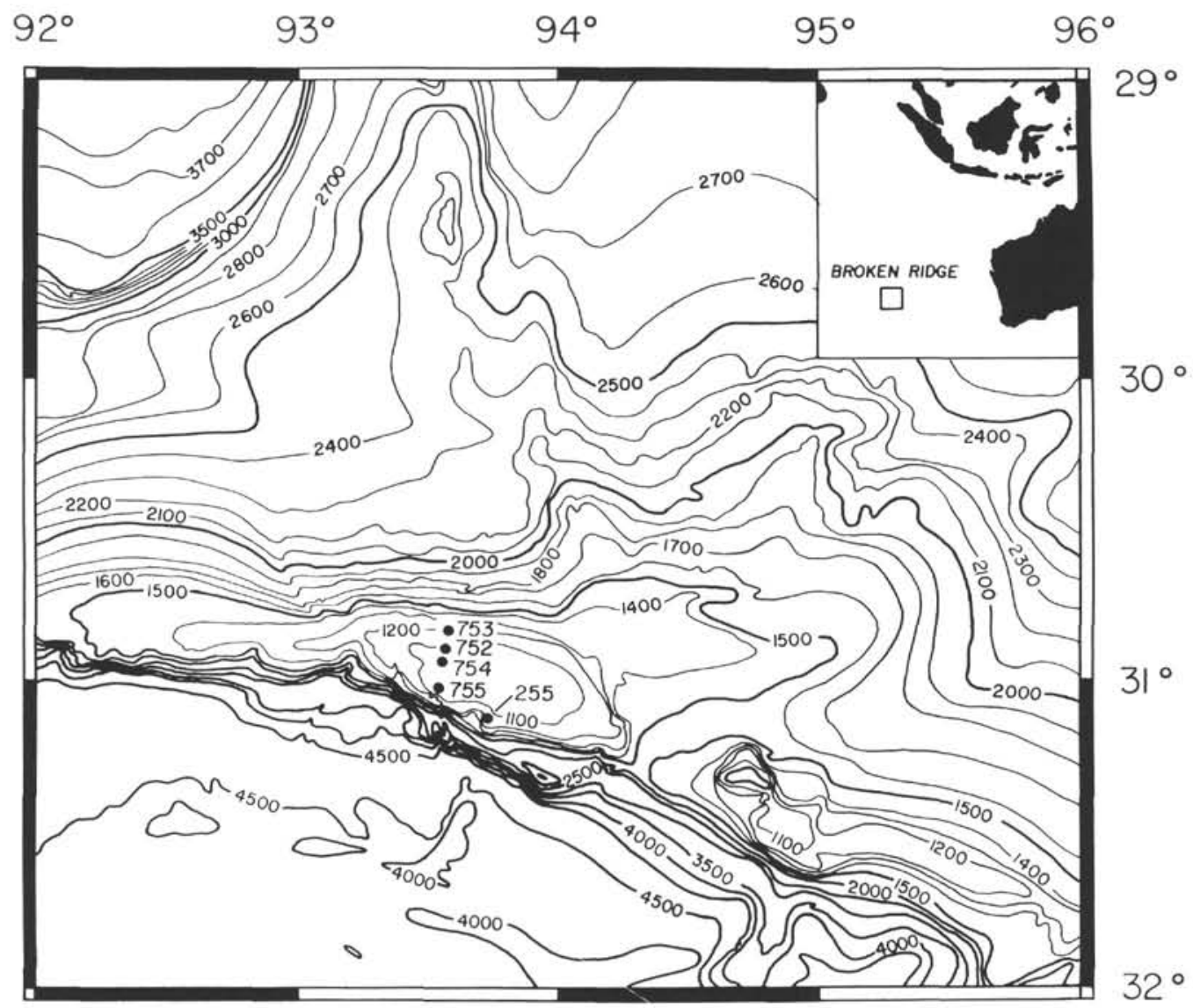

Figure 1. Bathymetry of Broken Ridge and location of ODP Sites 752-755.

volumes. At the beginning of the cruise, cross calibration of the three axes using an axially magnetized standard revealed that the $\mathrm{Z}$ component had been underestimated by approximately $6 \%$. Consequently, new calibration factors were determined $(\mathrm{X}=$ $\left.174.0 \times 10^{-6}, \mathrm{Y}=164.6 \times 10^{-6}, \mathrm{Z}=121.5 \times 10^{-6} \mathrm{emu} / \mathrm{phi} 0\right)$ and incorporated in the shipboard software.

Examination of the whole-core directional data revealed a bias in declination values, with declinations clustering between $0^{\circ}$ and $180^{\circ}$ (Peirce, Weissel, et al., 1989). Although such behavior is most prevalent in weakly lithified cores with low initial intensities recovered with the advanced hydraulic piston corer, it also occurs in some well-lithified cores recovered with the extended core barrel and rotary drilled, in which declinations of the individual fragments are expected to be randomly distributed. There is, however, generally a good correspondence between discrete sample and whole-core directions from the Paleogene to Upper Cretaceous sediments from Broken Ridge, suggesting that the declination bias arises either prior to or during splitting of the cores (for a more complete discussion see Peirce, Weissel, et al., 1989; Klootwijk et al., this volume). Regardless of the origin of the declination bias, whole-core inclination data are usually sufficient to determine polarity in the sediments discussed here because of the steep inclinations (the expected inclination range is $65^{\circ}-67^{\circ}$ ).

Discrete sample demagnetization studies were undertaken to refine the polarity determinations in cases where the 9-mT treatment of the archive half was insufficient to remove low-stability overprints. Poorly indurated sediments were sampled with $7-\mathrm{cm}^{3}$ Perspex cubes, and more lithified sediments were cut into $10-\mathrm{cm}^{3}$ cubes with a double-bladed diamond saw. Shipboard studies included stepwise alternating field (AF) and thermal demagnetiza- tion using a Schonstedt single-axis AF demagnetizer and thermal demagnetizer, respectively. Samples were measured with a Molspin magnetometer that has a sensitivity similar to that of the $2 \mathrm{G}$ magnetometer (approximately $10^{-9} \mathrm{Am}^{2}$ ). Although most samples exceeded this level, measurement of the majority of discrete samples was deferred for shore-based studies to allow more precise determination of directions.

All shore-based measurements were made in the shielded room $(<300 \mathrm{nT})$ of the Scripps paleomagnetic laboratory using a CTF three-axis cryogenic magnetometer. The sensitivity of the CTF magnetometer is approximately $10^{-12} \mathrm{Am}^{2}$ total moment. Alternating field and thermal demagnetization used equipment identical to that on board Resolution. Spurious magnetizations may be introduced during alternating field demagnetization at moderate to high fields. Thus, samples demagnetized at Scripps were routinely subjected to double demagnetization at treatment steps of $>20 \mathrm{mT}$. Samples were measured twice, once after demagnetization along three orthogonal axes and a second time following treatment along the opposite axial directions. Spurious components are readily recognized by deviations between the two measurements, and the Fischerian mean (for angular differences $<30^{\circ}$ ) of the measurements was used in determining characteristic magnetization directions. Characteristic magnetization directions were calculated using principal component analysis (Kirschvink, 1980). The directions have been corrected for the maximum regional dip $\left(2^{\circ}\right)$ by assuming a declination of $0^{\circ}$ for all normally magnetized samples and $180^{\circ}$ for all reversely magnetized samples. This structural correction provides an upper bound for the inclination because any deviation from the assumed declination (e.g., from apparent polar wander) would serve to reduce the correction. 


\section{LINE 20}

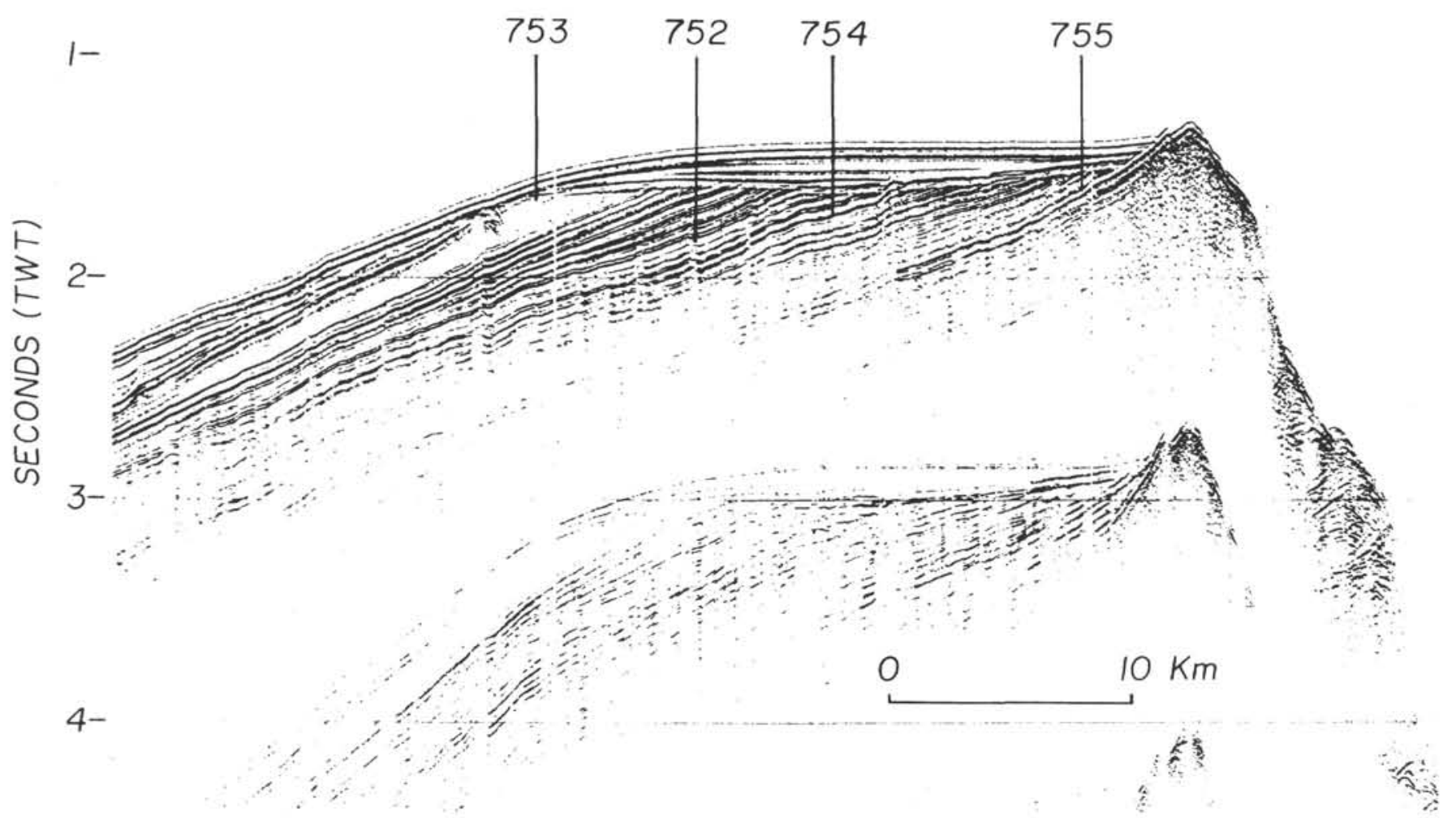

Figure 2. Seismic section approximately along the dip line of Broken Ridge. Location and depth of penetration of Holes 752-755 are shown. Lithologic Unit 1 comprises the horizontal upper Paleogene to Pleistocene sediments and Unit II the dipping $\left(1^{\circ}-2^{\circ}\right)$ and truncated lower Paleocene to Upper Cretaceous sequence.

In addition to demagnetization studies, the anisotropy of anhysteretic remanent magnetization (ARM) was determined for a small number of samples spaced throughout the prerift sequence. Anisotropy of ARM reflects the alignment of the remanence-carrying fraction (McCabe et al., 1985) and thus provides a means for assessing the role of compaction in producing anomalously shallow inclinations. Samples were subjected to an alternating field of $90 \mathrm{mT}$ and a $0.105-\mathrm{mT}$ bias field and then measured in the CTF magnetometer. The component of the ARM acquired parallel to the applied bias field in each of 24 orientations was used to determine the anisotropy tensor. Confidence estimates of the principal axes were calculated using the bootstrap technique of Constable and Tauxe (1990). Isothermal remanent magnetization acquisition was also determined for 26 samples using an impulse magnetizer (designed by J. Kirschvink) capable of producing instantaneous fields approaching $1 \mathrm{~T}$.

\section{DEMAGNETIZATION RESULTS}

We distinguish two general categories of demagnetization behavior in the sediments from Broken Ridge (Fig. 3). The highest quality data (type I) are characterized by well-defined high-stability components that decay linearly to the origin (Figs. $3 \mathrm{~A}$ and 3B). The median destructive field (MDF; the alternating field required to reduce the remanence to $50 \%$ of its initial value) of the type I samples is $>10 \mathrm{mT}$ and the characteristic magnetization typically has a maximum angular deviation of $<10^{\circ}$. Type II samples (Figs. 3C-3E) are considered less reliable for polarity and paleolatitude determinations. Samples are classified as type
II if either the characteristic magnetization is poorly defined or the sediment exhibits low stability during demagnetization. For example, the sample shown in Figure $3 \mathrm{C}$ has a large, low-stability component that is removed by $30 \mathrm{mT}$; however, the directional data at higher peak fields are unreliable due to the introduction of an ARM. Similarly, the low-stability components of the sample in Figure $3 \mathrm{D}$ are removed by $450^{\circ} \mathrm{C}$, but directions at temperatures $>550^{\circ} \mathrm{C}$ are spurious, presumably as a result of chemical changes. Although the polarity of these samples is adequately determined, the characteristic direction is defined by only a single or small number of steps. Samples with MDFs of $<10 \mathrm{mT}$, indicative of a low remanence stability, are suspect and are also classified as type II (Fig. 3E). A small number of samples yielded no polarity information, such as the sample shown in Figure 3F, and these samples have been excluded from further consideration. Finally, extremely shallow characteristic inclinations (e.g., Fig. 3G) were observed in some samples stratigraphically below approximately $340 \mathrm{~m}$ below seafloor (mbsf) in Hole 752B.

The majority of samples from Broken Ridge have maximum blocking temperatures of $500^{\circ}-600^{\circ} \mathrm{C}$ and MDFs of $10-25 \mathrm{mT}$, suggesting that the remanence is carried by magnetite. Several samples have blocking temperature spectra that extend to above $620^{\circ} \mathrm{C}$ (unblocking between the $620^{\circ}$ and $650^{\circ} \mathrm{C}$ steps). The magnetization remaining at $600^{\circ} \mathrm{C}$ is always less than $10 \%$ of the NRM intensity, suggesting a small contribution from hematite. Isothermal remanence acquisition reveals a range of behavior consistent with this interpretation (Fig. 4). A small number of samples fails to achieve saturation even in peak fields of $0.7 \mathrm{~T}$ 
A

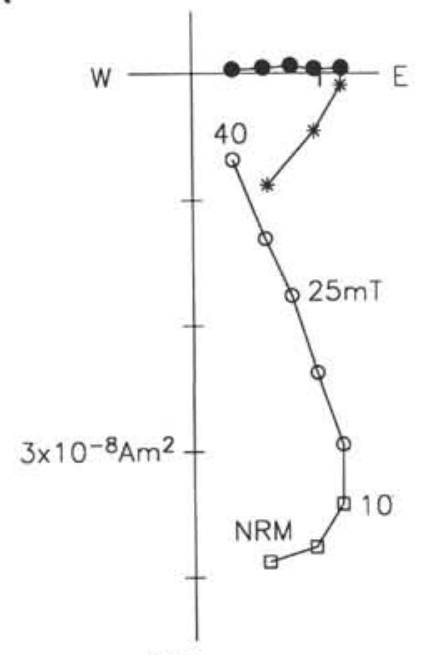

S,Down
E

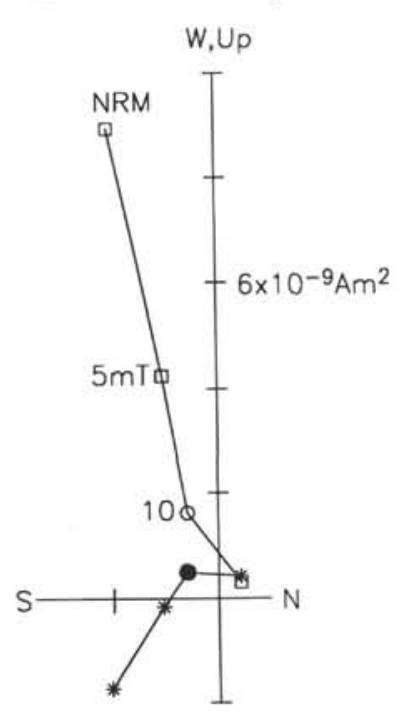

$$
121-755 \mathrm{~A}-13 \mathrm{r}-3,54 \mathrm{~cm}
$$

B

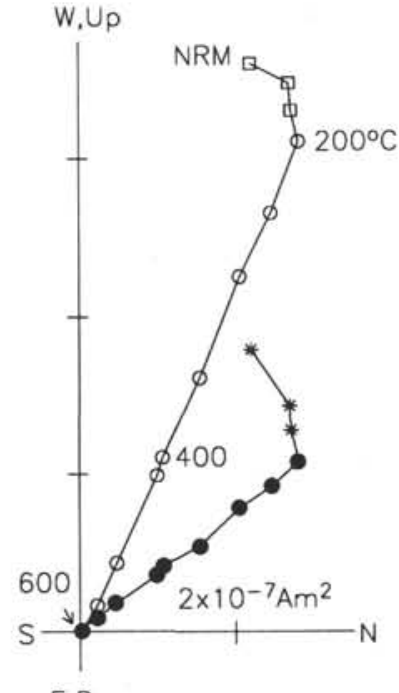

E,Down

F

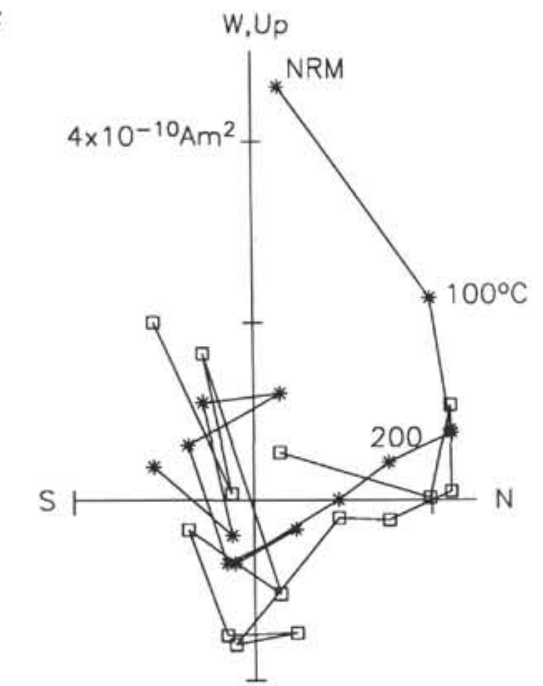

$121-752 \mathrm{~A}-14 \mathrm{x}-4,109 \mathrm{~cm}$

C

C

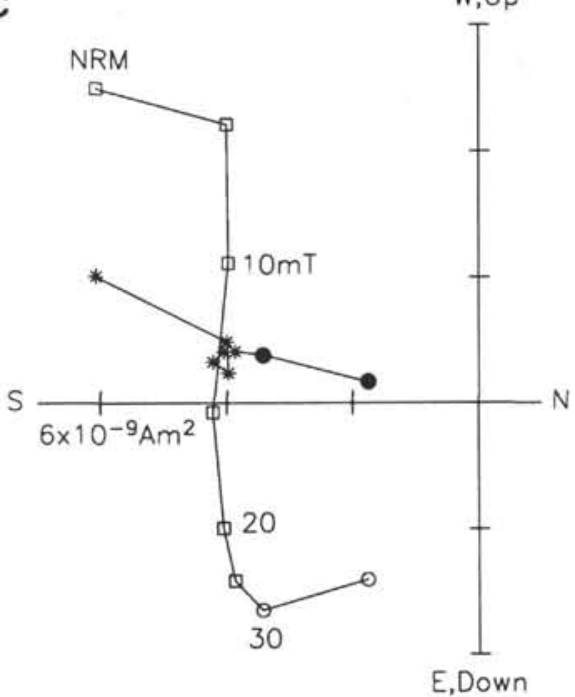

D

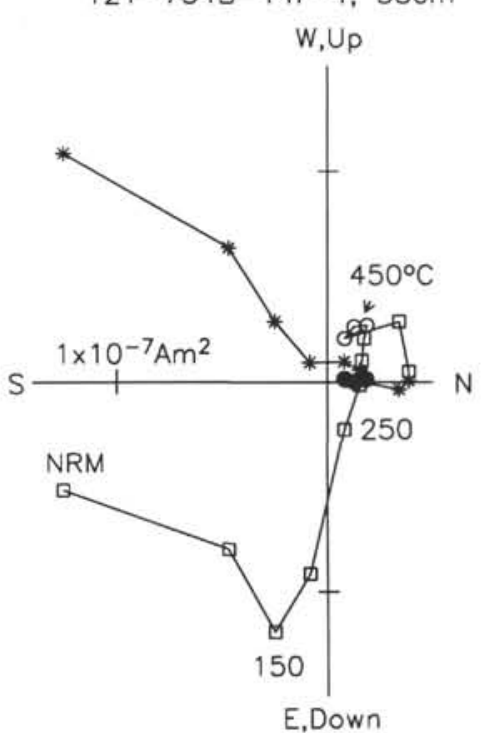

G
G $\quad 121-752 b-15 r-1,95 c m$

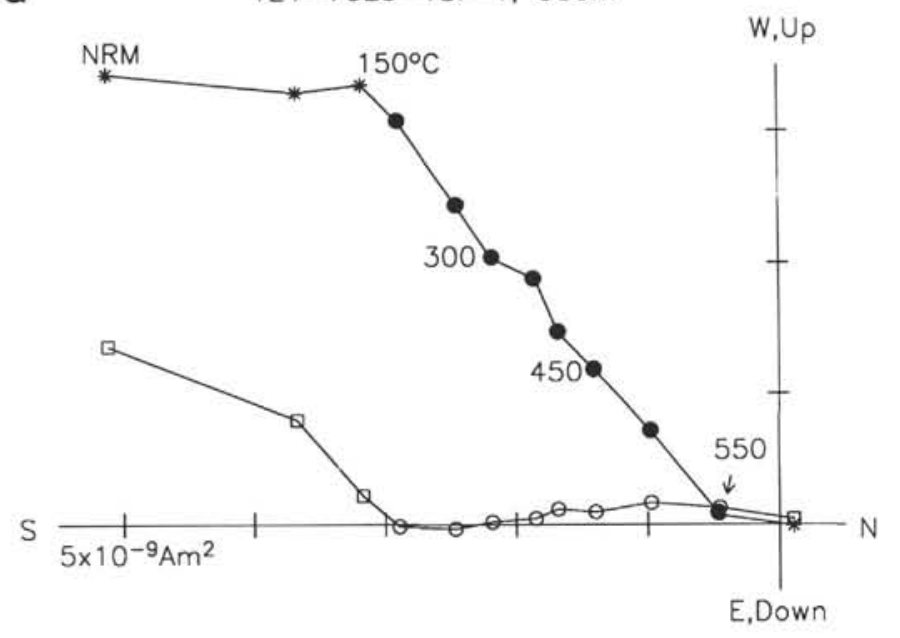

E,Down

E,Down

Figure 3. Representative vector end-point diagrams of sediments from Broken Ridge. Asterisks and solid circles represent projections onto the horizontal plane, squares and open circles onto the vertical plane. Open and solid circles are points used in calculating the characteristic magnetization. Alternating field (A) and thermal (B) demagnetization of type I sediments exhibit well-defined characteristic magnetizations that decay linearly to the origin. Samples may be classified as type II if the polarity is isolated by alternating field (C) or thermal (D) demagnetization, but the characteristic magnetization can be defined only by a single or small number of demagnetization steps. Samples with low median destructive fields (E) are suspect and are also classified as type II. A small number of samples yielded no polarity information (F). Extremely shallow inclinations $(\mathbf{G})$ may result in part from compaction or from components with opposing polarity but similar magnitudes and stability to demagnetization. 

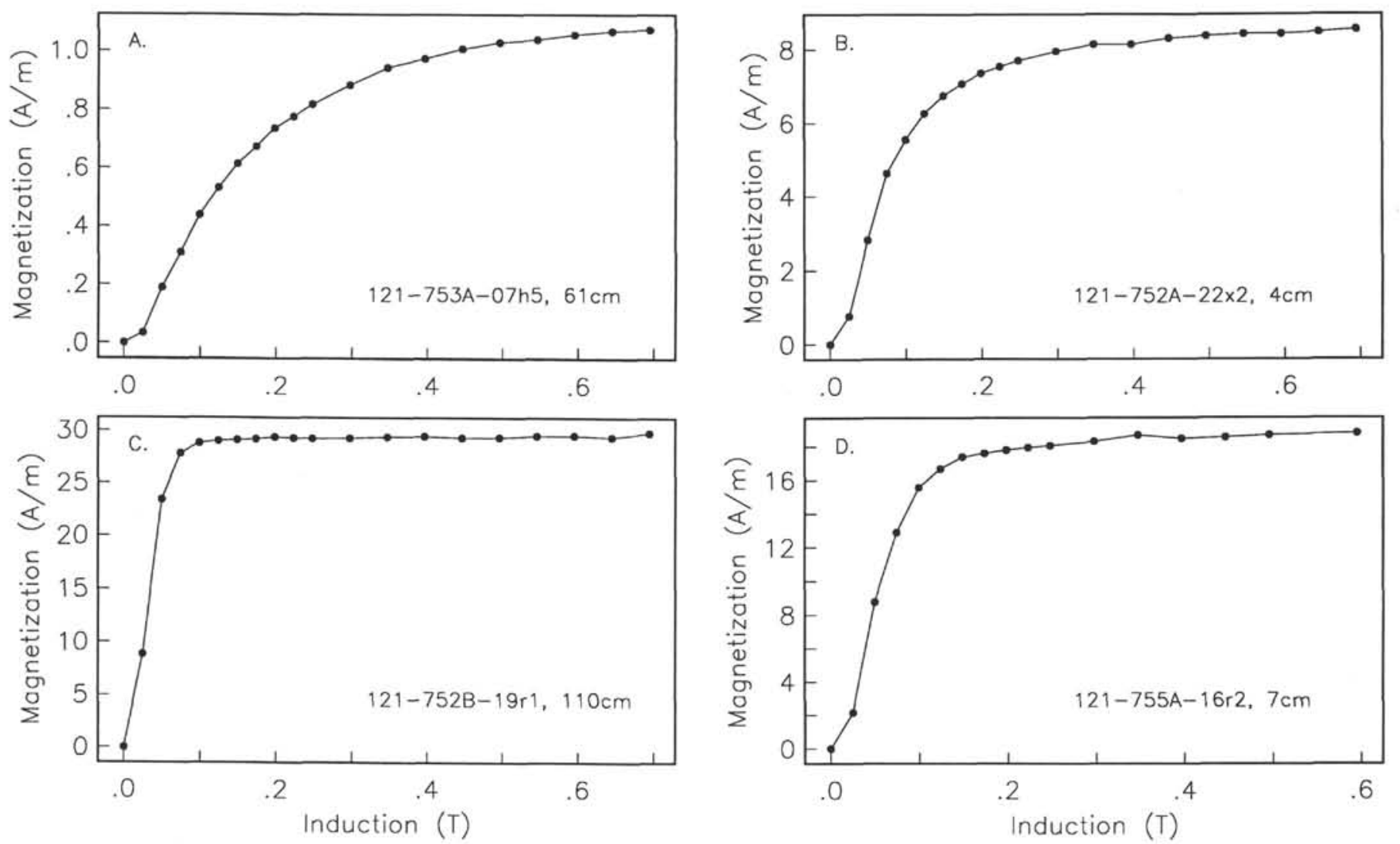

Figure 4. Range of isothermal remanence acquisition in samples from Broken Ridge. A. Sample dominated by high-coercivity phases such as hematite, as indicated by the continued increase in magnetization at fields $>0.3 \mathrm{~T}$. B. Sample with some contribution from hematite. Most samples achieve saturation at fields of $<0.3 \mathrm{~T}$ (C) or have only a small high field slope (D) consistent with magnetite as the dominant remanence-carrying mineral.

(Fig. 4A) indicating that high-coercivity phases such as hematite dominate the remanence. The majority of samples, however, achieve saturation at fields $<0.3 \mathrm{~T}$ (Fig. $4 \mathrm{C}$ ) or have small high field slopes (Figs. 4B and 4D), which are consistent with a magnetic mineralogy dominated by magnetite. Remanence contributions from both magnetite and hematite are commonly observed in marine limestones (Lowrie and Heller, 1982).

\section{MAGNETOSTRATIGRAPHIC RESULTS}

The polarity sequence defined by whole-core and discrete sample inclination data has been correlated to the GRTS (Berggren et al., 1985; Kent and Gradstein, 1985) with the aid of shipboard (Peirce, Weissel, et al., 1989) and more detailed shorebased biostratigraphic age determinations (see summary in Pospichal et al., this volume). Magnetostratigraphic results from the Paleogene-Upper Cretaceous sediments are given in Figures 5-9, and a summary of reversal depths and bracketing discrete samples is given in Table 1 .

\section{Site 752}

Holes $752 \mathrm{~A}$ and $752 \mathrm{~B}$ provide a $325-\mathrm{m}$ section of early Eocene to late Maestrichtian age sediments. Drill-string lengths and susceptibility measurements allow correlation between the two holes and indicate an offset of approximately $1 \mathrm{~m}$. Polarity data from Site 752 are generally of high quality (Fig. 5). With the exception of a short interval near 170 mbsf and the data from 240 to 300 mbsf, the whole-core inclination data after 9-mT demagnetization are sufficient to determine polarity to a depth of approximately 340 mbsf in the Paleogene sequence. The corresponding discrete sample data are mostly type I with moderate low-stability over- prints removed by $15 \mathrm{mT}$ or $300^{\circ}-350^{\circ} \mathrm{C}$. More substantial secondary components (stable to $25 \mathrm{mT}, 500^{\circ} \mathrm{C}$ ) were also noted, and these account for most of the observed discrepancies between the whole-core and discrete sample data (e.g., 170 and 240-300 mbsf). Low-stability overprints include steeply inclined directions probably induced during drilling, as well as both normal and reverse polarity directions with moderate inclinations (approximately $20^{\circ}-50^{\circ}$ ), which are more consistent with acquisition near the present latitude of Broken Ridge. The presence of both reversed and normal overprints is characteristic of the entire dipping and truncated sequence, indicating that these low-stability components are not of simple low-temperature viscous origin.

Whole-core data in the vicinity of the Cretaceous/Tertiary boundary ( $358.7 \mathrm{mbsf}$ ) are ambiguous and record several apparent polarity reversals (Fig. 6). Discrete samples from this interval include many type II demagnetization curves with substantial overprints generally of normal polarity. The prevalence and high stability $\left(20 \mathrm{mT}, 450^{\circ} \mathrm{C}\right)$ of these overprints makes the reversal boundaries in this interval suspect. Sediments from 380 to 400 mbsf are also of questionable reliability with abundant shallow inclinations and type II samples. Although recovery was poor, both whole-core and type I discrete sample inclinations indicate reversed polarity to the base of the hole.

The polarity record to a depth of approximately $340 \mathrm{mbsf}$ is readily correlated to the GRTS. The location of the Eocene/Paleocene (173.1 mbsf) and early Paleocene/late Paleocene (379.4 mbsf) boundaries suggests that the two relatively long reversed intervals correspond to Chrons C24R and C26R. Correlation of the upper two normal polarity intervals to Chron C24N is based on the occurrence of nannofossil Zones CP9a and CP9b (Resiwati, 

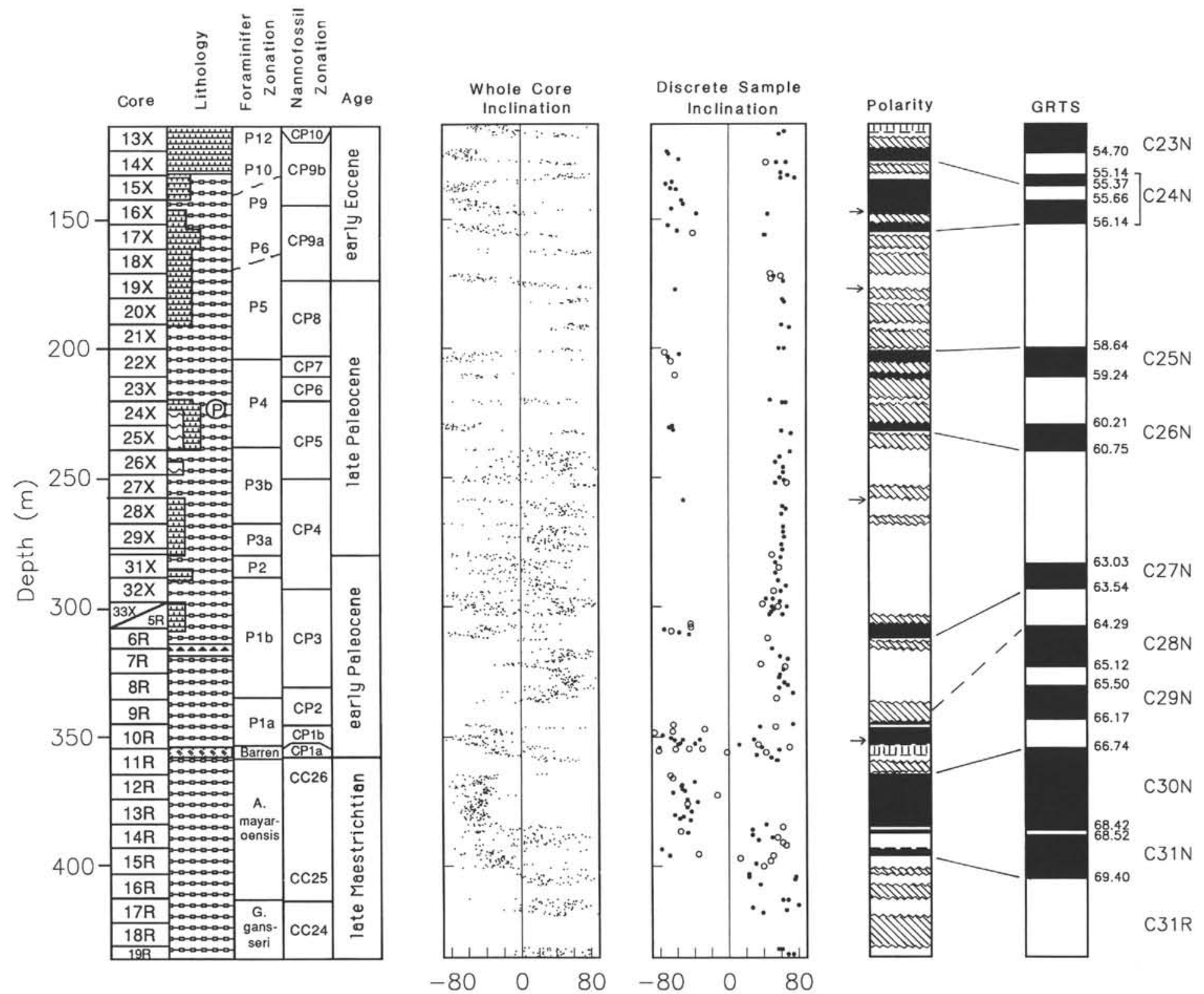

\section{Legend}

㯺慨慨 Nannofossil Chalk

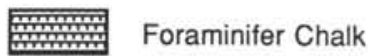

Calcareous Chalk

ring Radiolarite

anses Chert

Bgas Volcanic Ash

(P) Pyrite

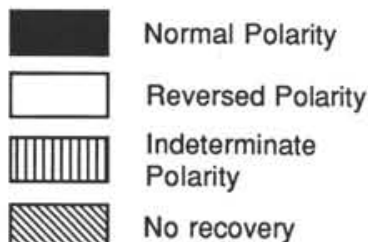

Figure 5. Lithology, biostratigraphy, and magnetostratigraphy of sediments from Hole 752. Depth in meters sub-bottom. The whole-core inclination data are after 9-mT demagnetization. Discrete samples with type I demagnetization behavior are plotted as solid circles and type II samples as open circles. Isolated samples of opposite polarity are marked by arrows to the left of the polarity column, and our preferred correlation to the GRTS is shown on the right. Ages of reversal boundaries and chron terminology are from Berggren et al. (1985) and Kent and Gradstein (1985). 
Table 1. Summary of reversal boundaries.

\begin{tabular}{|c|c|c|c|}
\hline \multirow{2}{*}{$\begin{array}{l}\text { Depth } \\
\text { (mbsf) }\end{array}$} & \multirow[b]{2}{*}{ Transition } & \multicolumn{2}{|c|}{$\begin{array}{c}\text { Nearest discrete samples } \\
\text { (Core, section, interval in } \mathrm{cm} \text { ) }\end{array}$} \\
\hline & & Above (mbsf) & Below (mbsf) \\
\hline \multicolumn{4}{|l|}{ Hole $752 \mathrm{~A}$} \\
\hline 116.5 & Base indeterminate zone & - & $13 X-3,85(116.75)$ \\
\hline $118.4-122.6$ & $\mathrm{~N}$ to $\mathrm{R}$, top of $\mathrm{C} 24 \mathrm{~N}-1$ & - & - \\
\hline 127.5 & $R$ to $N$, base of $C 24 N-1$ & $14 X-3,122(126.82)$ & $14 X-4,91(128.01)$ \\
\hline 135.0 & $\mathrm{~N}$ to $\mathrm{R}$, top of $\mathrm{C} 24 \mathrm{~N}-2$ & $15 X-2,75(134.55)$ & $15 X-3,60(135.53)$ \\
\hline 154.9 & $\mathrm{R}$ to $\mathrm{N}$, base of $\mathrm{C} 24 \mathrm{~N}-2$ & $17 X-2,121(154.41)$ & $17 X-3,60(155.30)$ \\
\hline 201.1 & $\mathrm{~N}$ to $\mathrm{R}$, top of $\mathrm{C} 25 \mathrm{~N}$ & $22 X-1,41(200.51)$ & $22 X-2,04(201.64)$ \\
\hline $211.5-219.5$ & $\mathrm{R}$ to $\mathrm{N}$, base of $\mathrm{C} 25 \mathrm{~N}$ & - & - \\
\hline $221.7-229.1$ & $\mathrm{~N}$ to $\mathrm{R}$, top of $\mathrm{C} 26 \mathrm{~N}$ & - & - \\
\hline 232.1 & $\mathrm{R}$ to $\mathrm{N}$, base of $\mathrm{C} 26 \mathrm{~N}$ & $25 X-2,111(231.70)$ & $25 X-3,73(232.83)$ \\
\hline \multicolumn{4}{|l|}{ Hole 752B } \\
\hline $303.6-306.7$ & $\mathrm{~N}$ to $\mathrm{R}$, top of $\mathrm{C} 27 \mathrm{~N}$ & - & - \\
\hline 312.2 & $\mathrm{R}$ to $\mathrm{N}$, base of $\mathrm{C} 27 \mathrm{~N}$ & $6 \mathrm{R}-3,102(310.62)$ & $6 \mathrm{R}-4,147(312.57)$ \\
\hline $336.8-345.1$ & $\mathrm{~N}$ to $\mathrm{R}$, top of $\mathrm{C} 28 \mathrm{~N}$ & - & - \\
\hline$a_{345.3}$ & $\mathrm{R}$ to $\mathrm{N}$, base of $\mathrm{C} 28 \mathrm{~N}$ & $10 \mathrm{R}-1,16(345.26)$ & $10 \mathrm{R}-1,35(345.45)$ \\
\hline$a_{346.8}$ & $\mathrm{~N}$ to $\mathrm{R}$, top of $\mathrm{C} 29 \mathrm{~N}$ & $10 \mathrm{R}-1,103$ (346.13) & $10 \mathrm{R}-2,38$ (346.98) \\
\hline $\mathrm{a}_{353.1}$ & Top of indeterminate zone & $10 \mathrm{R}-6,32(359.92)$ & $10 \mathrm{R}-6,61(353.21)$ \\
\hline$a_{357.2}$ & Base of indeterminate zone & - & $11 \mathrm{R}-2,94$ (357.42) \\
\hline$b_{364.7}$ & $\mathrm{~N}$ to $\mathrm{R}$, top of $\mathrm{C} 30 \mathrm{~N}$ & - & $12 \mathrm{R}-1,61(365.01)$ \\
\hline $\mathrm{a}_{384.8}$ & $\mathrm{R}$ to $\mathrm{N}$, top of reversed zone & $14 \mathrm{R}-1,26(383.86)$ & $14 \mathrm{R}-1,129(384.89)$ \\
\hline$a_{386.4}$ & $\mathrm{~N}$ to $\mathrm{R}$, base of reversed zone & $14 \mathrm{R}-2,124(386.34)$ & $14 \mathrm{R}-3,14(386.74)$ \\
\hline $\mathrm{a}_{387.5}$ & $\mathrm{R}$ to $\mathrm{N}$, base of $\mathrm{C} 30 \mathrm{~N}$ & $14 \mathrm{R}-3,66(387.26)$ & $14 \mathrm{R}-4,28(388.38)$ \\
\hline$a_{392.9-393.3}$ & $\mathrm{~N}$ to $\mathrm{R}$, top of $\mathrm{C} 31 \mathrm{~N}$ & - & - \\
\hline 396.2 & $R$ to $N$, base of $C 31 \mathrm{~N}$ & $15 \mathrm{R}-2,115(395.95)$ & $15 R-3,4(396.34)$ \\
\hline \multicolumn{4}{|l|}{ Hole 753A } \\
\hline${ }^{a} 46.6$ & $\mathrm{R}$ to $\mathrm{N}$, base of $\mathrm{C} 20 \mathrm{~N}$ & $6 \mathrm{H}-2,63(45.73)$ & $6 \mathrm{H}-3,63(47.23)$ \\
\hline \multicolumn{4}{|l|}{ Hole 754B } \\
\hline${ }^{a} 154.9$ & $\mathbf{R}$ to $\mathrm{N}$, base of normal zone & $5 R-2,115$ (154.35) & 5R-3, 109 (155.79) \\
\hline 176.6 & $\mathrm{~N}$ to $\mathrm{R}$, top of $\mathrm{C} 32 \mathrm{~N}-1$ & $7 R-4,29(175.79)$ & $7 R-5,35(177.35)$ \\
\hline 191.7 & $\mathrm{R}$ to $\mathrm{N}$, base of $\mathrm{C} 32 \mathrm{~N}-1$ & 9R-1, 17 (190.47) & $9 \mathrm{R}-2,110(192.90)$ \\
\hline 211.1 & $\mathrm{~N}$ to $\mathrm{R}$, top of $\mathrm{C} 32 \mathrm{~N}-2$ & $11 \mathrm{R}-1,123(210.83)$ & $11 \mathrm{R}-2,24(211.34)$ \\
\hline${ }^{a} 212.6-219.2$ & $\mathrm{R}$ to $\mathrm{N}$, top of reversed zone & $-(2 x)$ & - \\
\hline$a_{220.7-229.9}$ & $\mathrm{~N}$ to $\mathrm{R}$, base of reversed zone & - & - \\
\hline $299.3-306.3$ & $\mathrm{R}$ to $\mathrm{N}$, base of $\mathrm{C} 32 \mathrm{~N}-2$ & - & - \\
\hline
\end{tabular}

this volume; Berggren et al., 1985). Foraminifer zonations in this interval are uncertain but suggest an early to middle Eocene age (van Eijden and Smit, this volume; Berggren et al., 1985). Additional biostratigraphic datum levels are in good agreement with the polarity interpretation shown in Figure 5 (Pospichal et al., this volume).

The location of the Cretaceous/Tertiary boundary, generally accepted to lie within Chron C29R (Berggren et al., 1985), constrains the correlation in the lower part of the section. The relative condensation of sediments corresponding to Chrons C28 and C29 is consistent with a significant decrease in the overall mass-accumulation rate (MAR) in the 1.5-m.y. interval following the Cretaceous/Tertiary boundary (Rea et al., 1990; Owen and Zimmerman, this volume). Revised nannofossil zonations (Resiwati, this volume; Pospichal, this volume) and the magnetostratigraphy shown in Figures 5 and 6 suggest a somewhat smaller reduction in total MAR (approximately $50 \%$ ) during this interval in comparison with the more than threefold reduction concluded from the preceding studies. The identification of Chron C28R (Fig. 6) is tentative but is consistent with the first occurrence of Chiasmolithus danicus (base of Zone CP2, 65.0 Ma; Berggren et al., 1985) at 345.1 mbsf (Peirce, Weissel, et al., 1989).

The boundary between nannofossil Zone CC24 and the interval assigned to Zones CC25/26 at 416.8 mbsf (Resiwati, this volume; Sissingh, 1977) indicates that the lowermost reversed interval corresponds to Chron C31R (Kent and Gradstein, 1985). In view of the limited reliability of discrete sample results from 385 to 400 mbsf and the presence of an additional reversed interval, the boundaries of Chron C30R cannot be unambiguously determined. We also note that the low MDFs of samples from 395 to 400 mbsf allow the possible extension of Chron C $31 \mathrm{~N}$ to approximately $400 \mathrm{mbsf}$, in which case the relative length of Chron C31N would be more consistent with the GRTS. Of the four short polarity events (arrows in Fig. 5), those near the base of $\mathrm{C} 24 \mathrm{~N}$ and within C24R are consistent with whole-core data and may represent short polarity events not represented in the GRTS. Meaningful information in the marine magnetic anomaly record, which serves as a template for the GRTS, is limited to wavelengths of $>4 \mathrm{~km}$ (Miller, 1977). Thus, at a spreading rate of 10 $\mathrm{cm} / \mathrm{yr}$, geomagnetic features of less than 40,000-yr duration are not represented in the sea surface records or, consequently, in the GRTS. The remaining two short polarity events may also represent short reversals or alternatively may reflect incomplete isolation of the primary magnetization or sample misorientation.

\section{Site 753}

The youngest sediments from lithologic Unit II, below the Eocene unconformity, were sampled at Site 753. Seismic correla- 


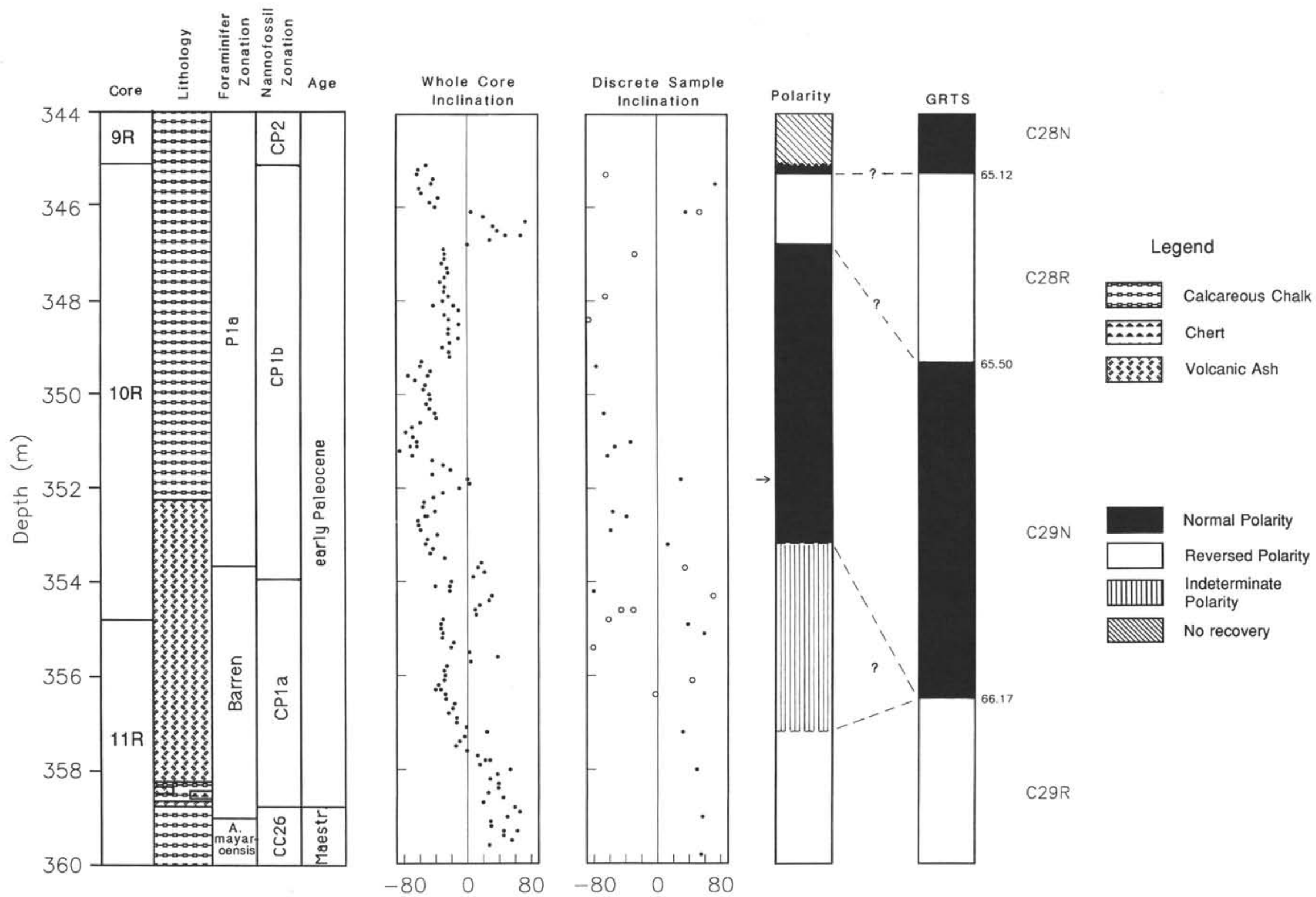

Figure 6. Lithology, biostratigraphy, and magnetostratigraphy of sediments from Hole 752B in the vicinity of the Cretaceous/Tertiary boundary ( 358.7 mbsf). Conventions as in Figure 5. 
tions indicate a stratigraphic gap of approximately $190 \mathrm{~m}$ between the uppermost lower Paleocene sediments of Hole 752A and the middle Eocene sediments at the base of Hole 753A (Peirce, Weissel, et al., 1989). Although the whole-core data are ambiguous, nine type I samples clearly establish the reversed polarity of the majority of the section (Fig. 7). The low MDFs of the upper two samples make this normal polarity interval suspect. Biostratigraphic data (van Eijden and Smit, this volume; Resiwati, this volume) are ambiguous and permit correlation of the reversed interval to Chrons C18R through C20R. As noted by Pospichal et al. (this volume), correlation to Chron C18 is unlikely because magnetic anomaly 18 has been identified to the south of Broken Ridge (Mutter and Cande, 1983).

\section{Site 754}

Hole 754B represents the continuation of the sequence sampled in Holes 752A and 752B, although the precise amount of overlap between the sites is uncertain (Fig. 8). Nannofossil biostratigraphy (Resiwati, this volume) indicates an overlap of less than $20 \mathrm{~m}$, constrained by the presence of nannofossil Zone CC24 (Sissingh, 1977) in both Holes 752B and 754B and the location of the CC25/CC24 boundary at a depth of $417 \mathrm{mbsf}$ in Hole 754B. This is consistent with the amount of overlap $(20 \pm 20 \mathrm{~m})$ inferred from seismic stratigraphy (Peirce, Weissel, et al., 1989). Similarly, the assignment of Core 121-754B-5R to the Abathomphalus mayaroensis Zone is also compatible with an overlap of approximately $20 \mathrm{~m}$ (van Eijden and Smit, this volume). Hole 754A penetrated the upper $12 \mathrm{~m}$ of sediment below the Eocene unconformity with an average recovery of $73 \%$. Although not figured, the results from Hole 754A are incorporated in the following discussion.

Whole-core inclination data alone are of limited use in determining the polarity of Hole 754B, but when augmented by discrete sample data provide a reasonable reversal stratigraphy (Fig. 8). Nearly three-quarters of the discrete samples exhibit type I behavior, with low-stability overprints generally removed by 15 $\mathrm{mT}$ or $300^{\circ} \mathrm{C}$. In contrast, the central portion of the section (230-255 mbsf) has abundant type II samples, and both wholecore and discrete sample inclinations record several short polarity events (arrows in Fig. 8). Many of the discrete samples from this interval exhibit pronounced secondary magnetizations of reversed polarity which are stable to demagnetization levels of $30 \mathrm{mT}$ and $450^{\circ} \mathrm{C}$. The comparably large, reversed polarity secondary magnetizations also noted in samples from 210 to 212 mbsf may cast doubt the validity of the short reversed polarity interval in the underlying core (approximately $220 \mathrm{mbsf}$ ). The presence of such large reversed polarity overprints suggests that many of the isolated reversed samples in this interval represent incompletely removed secondary magnetizations or completely remagnetized samples. Alternatively, the presumably rapid and episodic deposition of these ash-rich sediments may record short polarity events unrepresented in the GRTS.

Our preferred correlation to the GRTS relies heavily on the biostratigraphically determined overlap (approximately $20 \mathrm{~m}$ ) with Hole 752B and the early Maestrichtian age of the base of Hole 754B (nannofossil Zone CC23b; Resiwati, this volume). Van Eijden and Smit (this volume) suggested that the Campanian/Maestrichtian boundary lies within Core 121-754B-11R based on the presence of common Heterohelix punctulata; however, the lack of foraminifer marker species prevented zonation of the sediments below Core 121-754B-5R. The $20-\mathrm{m}$ overlap with Hole 752B implies that the uppermost reversed interval corresponds to Chron C31R. We interpret the 3.2-m normal interval directly below the Eocene unconformity as a product of remagnetization. The short section recovered below the unconformity in Hole 754A also confirms the presence of this normal zone, although the base of the normal interval occurs at a slightly greater depth (approximately $160 \mathrm{mbsf}$ ). The remaining discrete samples from Hole 754A, with the exception of a single sample at $165.8 \mathrm{mbsf}$, all indicate reversed polarity and are thus consistent with the polarity inferred from Hole 754B. The majority of the sediments from Hole 754B are correlated to Chron C32. We note that the 490-m gap separating Hole 754B from the TuronianSantonian tuffs of Hole 755A requires an average linear sedimentation rate similar to that within Chron C32. Assuming that the top of Chron C33 lies slightly below the base of Hole 754B and the top of $\mathrm{C} 34 \mathrm{~N}$ occurs slightly higher than the highest sediments from Hole 755A gives linear sedimentation rates of 54-75 m/m.y. within Chron $\mathrm{C} 32$ and rates of approximately $50 \mathrm{~m} / \mathrm{m}$.y. for the intervening gap. Thus, the large stratigraphic gap between the Holes 754B and 755A makes a gross error in the correlation of the polarity sequence of Hole 754B with the GRTS unlikely.

\section{Site 755}

Results from Hole 755A (Fig. 9) are of very high quality but are of little chronostratigraphic value because the section lies entirely within the Cretaceous quiet zone (Chron C34N). With the exception of a short interval at a depth of $132 \mathrm{mbsf}$, both wholecore and discrete samples indicate normal polarity throughout. Discrete sample demagnetization curves are almost exclusively of type I with nearly univectorial magnetizations (four type II curves out of 74 total). The moderate MDFs (15-20 mT), uniformly high blocking temperatures $\left(550^{\circ}-620^{\circ} \mathrm{C}\right)$, and saturation of isothermal remanence in fields of $<0.3 \mathrm{~T}$ indicate a stable remanence carried predominantly by magnetite. The single reversed sample (132.5 mbsf) is consistent with positive whole-core inclinations in this interval and may represent a short reversal within Chron C34N. Unfortunately, biostratigraphic zonations for Site 755 are uncertain due to the poor preservation, lack of diagnostic forms, and the high latitude of Broken Ridge during the Cretaceous. Nannofossil zonations indicate an age range from late Turonian to late Santonian for Hole $755 \mathrm{~A}$, with a probable Coniacian age for the single reversed sample from Core 121755A-12R (Pospichal et al., this volume). Despite detailed sampling (corresponding to 50,000-200,000 yr) of the upper portion of Chron $\mathrm{C} 34 \mathrm{~N}$ in the Umbrian Apennines (Lowrie and Alvarez, 1977; Alvarez and Lowrie, 1978) no reversed polarity intervals are known within the Coniacian.

\section{INCLINATION DATA}

Average inclinations were calculated for each hole (Table 2) using the method of McFadden and Reid (1982) for azimuthally unoriented data. These inclinations have been corrected for the maximum $\left(2^{\circ}\right)$ regional dip as outlined previously. Mean normal and reversed polarity inclinations (type I samples only) within each hole were compared using the $t$ statistic. The mean inclinations for reversed and normal samples are statistically different (95\% confidence level) for Hole 754B. Normal and reversed means for Holes 752A and 752B are statistically indistinguishable and the remaining two holes have only a single polarity (one reversed sample in the case of Hole $755 \mathrm{~A}$ ). The cause of this inclination discrepancy in samples from Hole 754B is not clear, but it may result from the incomplete removal of a pervasive lower stability component. Because the magnitude and sign of this discrepancy between normal and reversed polarity inclinations varies from site to site, we use the combined mean inclination in the following discussion.

Several observations suggest that the paleolatitude of Broken Ridge during deposition of lithologic Unit II was probably $47^{\circ}-$ $50^{\circ} \mathrm{S}$. Basement paleolatitudes from Ninetyeast Ridge (Peirce, 1978; Klootwijk et al., this volume) are compatible with a hot-spot origin at approximately $50^{\circ} \mathrm{S}$, the present location of the Ker- 

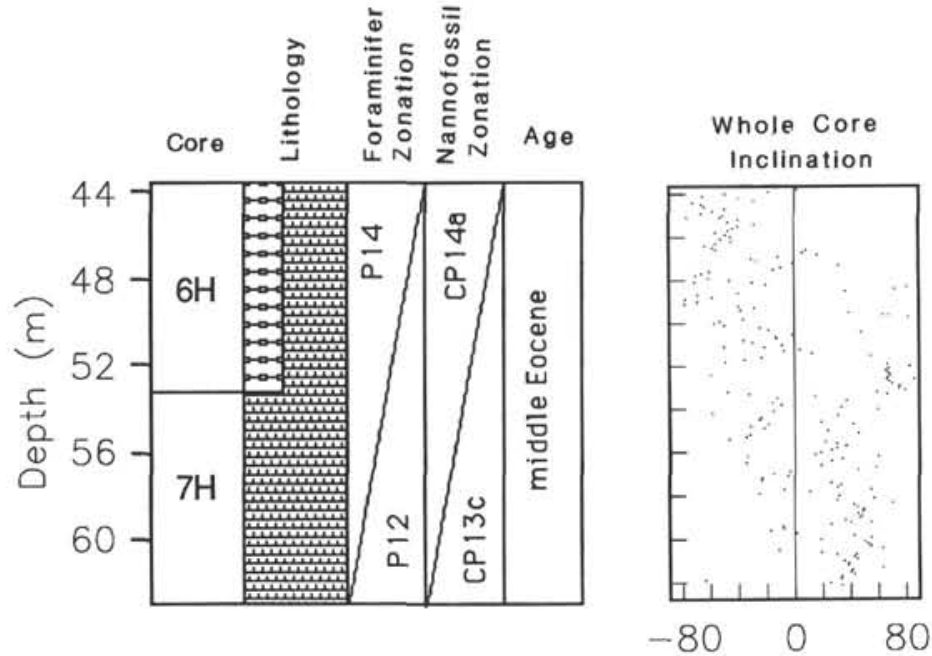

Discrete Sample

Inclination

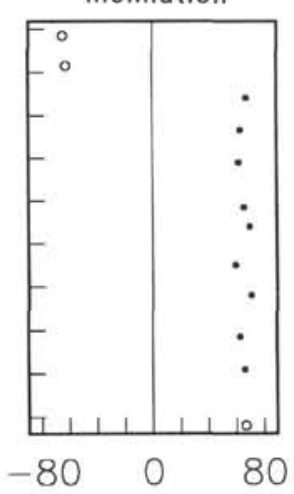

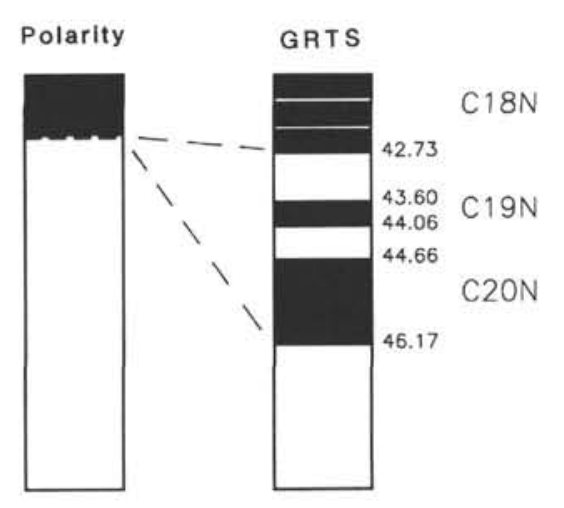

Legend

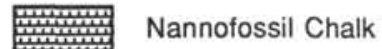

Calcareous Chalk

Normal Polarity

Reversed Polarity

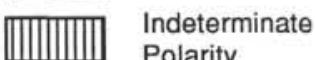

Polarity

No recovery

Figure 7. Lithology, biostratigraphy, and magnetostratigraphy of sediments from Hole 753A. Conventions as in Figure 5. 

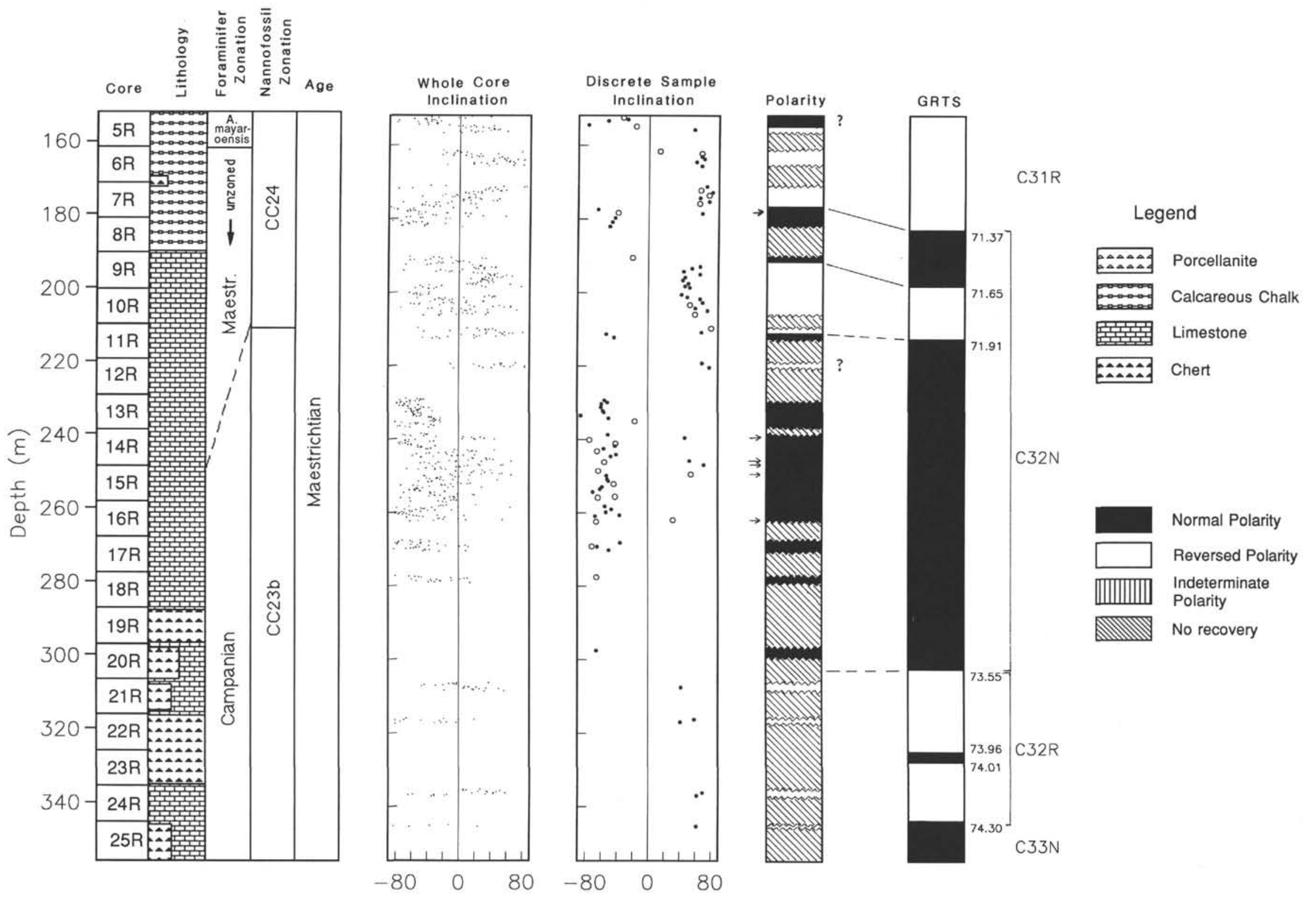

Figure 8. Lithology, biostratigraphy, and magnetostratigraphy of sediments from Hole 754B. Question marks denote uncertain polarity determinations as discussed in the test. Conventions as in Figure 5. 

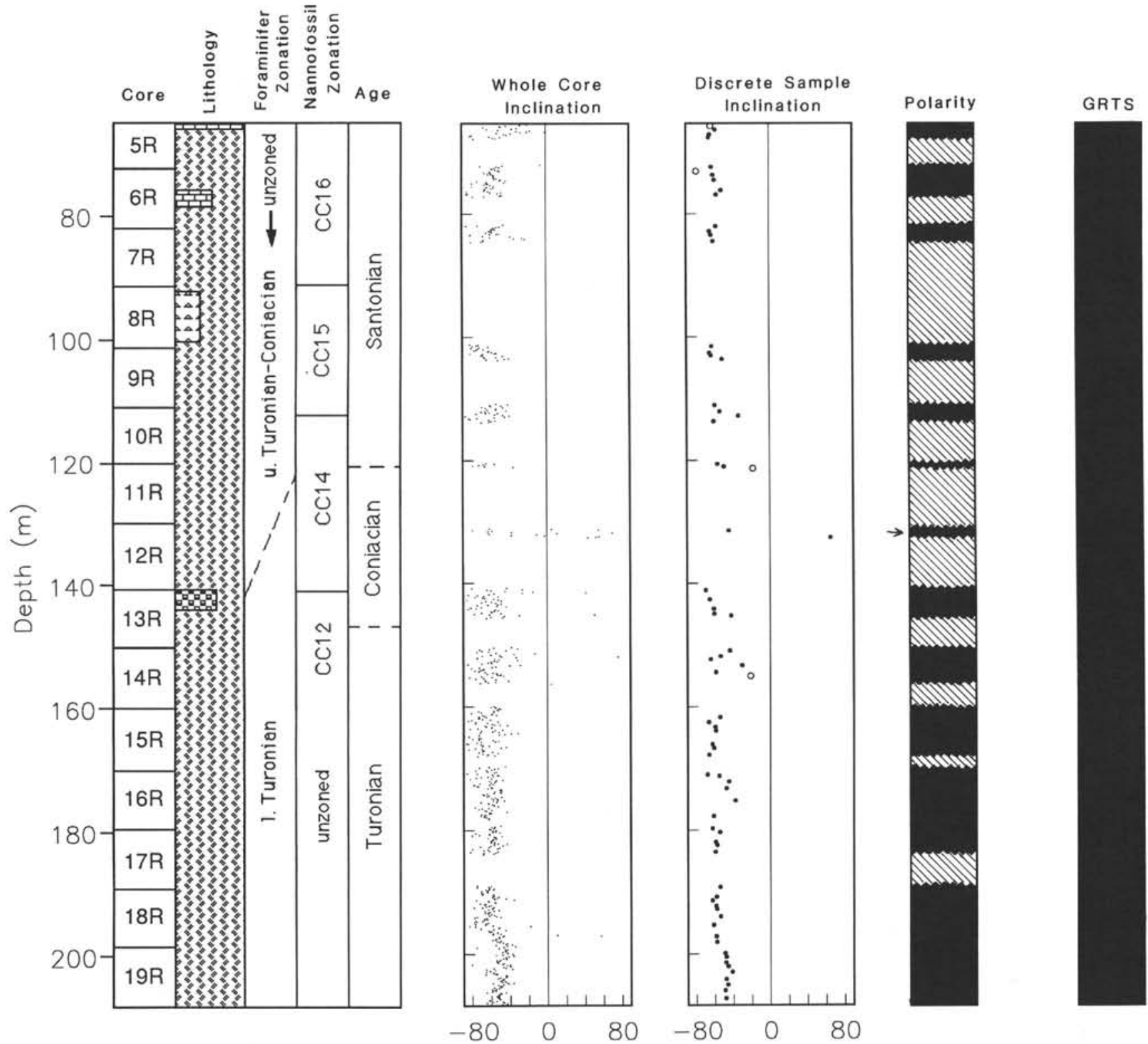

Legend

亞

Porcellanite

Volcanic Ash

खam Glauconite

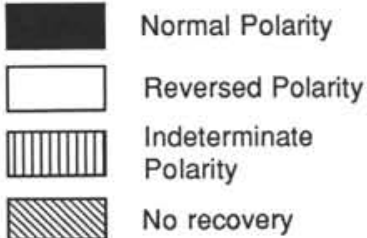

Figure 9. Lithology, biostratigraphy, and magnetostratigraphy of sediments from Hole 755A. Conventions as in Figure 5 . 
Table 2. Mean inclination data for Broken Ridge sites.

\begin{tabular}{|c|c|c|c|c|c|c|}
\hline \multirow[b]{2}{*}{ Data $^{a}$} & \multirow[b]{2}{*}{$n$} & \multirow{2}{*}{$\begin{array}{c}\text { Maximum } \\
\text { likelihood } \\
\text { inclination } \\
\text { (degrees) }\end{array}$} & \multicolumn{2}{|c|}{$\begin{array}{c}95 \% \\
\text { Confidence } \\
\text { interval }\end{array}$} & \multirow[b]{2}{*}{ Alpha $^{c}$} & \multirow[b]{2}{*}{ Kapp } \\
\hline & & & Upper & Lower & & \\
\hline \multicolumn{7}{|l|}{ Hole $752 \mathrm{~A}$} \\
\hline All & 85 & 62.9 & +1.2 & -3.8 & 2.5 & 43.9 \\
\hline Type I & 71 & 63.7 & +1.3 & -3.6 & 2.5 & 51.4 \\
\hline $\mathrm{N}$ & 20 & -65.5 & +6.4 & -3.6 & 5.0 & 43.2 \\
\hline $\mathbf{R}$ & 51 & $62.9^{\circ}$ & +1.7 & -3.7 & 2.7 & 55.4 \\
\hline \multicolumn{7}{|l|}{ Hole 752B } \\
\hline All & 110 & 59.3 & +1.4 & -11.0 & 6.2 & 10.4 \\
\hline Type I & 76 & 59.8 & +1.9 & -10.9 & 6.4 & 11.3 \\
\hline $\mathrm{N}$ & 29 & -60.1 & +8.6 & -3.7 & 6.2 & 20.3 \\
\hline $\mathbf{R}$ & 47 & 59.5 & +3.1 & -14.6 & 8.9 & 8.8 \\
\hline \multicolumn{7}{|c|}{ Holes $752 \mathrm{~A}$ and $752 \mathrm{~B}$} \\
\hline All & 195 & 61.3 & +0.7 & -8.0 & 4.4 & 14.9 \\
\hline Type I & 147 & 62.1 & +0.9 & -7.4 & 4.2 & 17.1 \\
\hline $\mathrm{N}$ & 49 & -62.6 & +6.8 & -2.2 & 4.5 & 24.2 \\
\hline $\mathbf{R}$ & 98 & 61.8 & +1.4 & -8.8 & 5.1 & 14.8 \\
\hline \multicolumn{7}{|l|}{ Hole 753A } \\
\hline All & 12 & 67.3 & +2.3 & -2.7 & 2.5 & 295.5 \\
\hline Type I & 9 & 67.5 & +3.2 & -3.7 & 3.4 & 236.5 \\
\hline $\mathrm{N}$ & - & - & - & - & - & - \\
\hline $\mathbf{R}$ & 9 & 67.5 & +3.2 & -3.7 & 3.4 & 236.5 \\
\hline \multicolumn{7}{|l|}{ Hole 754B } \\
\hline All & 100 & 61.3 & +1.4 & -8.5 & 5.0 & 15.0 \\
\hline Type I & 74 & 61.4 & +1.7 & -6.4 & 4.0 & 22.5 \\
\hline $\mathrm{N}$ & 37 & -57.0 & +6.5 & -3.0 & 4.7 & 25.4 \\
\hline $\mathbf{R}$ & 37 & 65.5 & +2.6 & -7.8 & 5.2 & 24.2 \\
\hline \multicolumn{7}{|l|}{ Hole 755A } \\
\hline All & 74 & 59.1 & +1.6 & -4.8 & 3.2 & 30.6 \\
\hline Type I & 70 & 59.0 & +1.5 & -3.4 & 2.5 & 48.6 \\
\hline $\mathrm{N}$ & 69 & -59.2 & +3.4 & -1.5 & 2.5 & 49.4 \\
\hline $\mathbf{R}$ & 1 & 64.9 & - & - & - & - \\
\hline
\end{tabular}

${ }^{\text {a }}$ All $=$ combined normal and reversed means using absolute values of negative inclinations.

${ }^{b}$ Means and error estimates calculated with the method of McFadden and Reid (1982). Inclinations were corrected for maximum $\left(2^{\circ}\right)$ dip, as explained in text.

$c$ Half-width of the $95 \%$ confidence interval.

guelen hot spot. Similarly, the Rajmahal Traps (approximately $115 \mathrm{Ma}$; Baksi, 1986) suggest a paleolatitude of $47^{\circ} \mathrm{S}$ for the hot spot during the Early Cretaceous (Klootwijk, 1971). Tectonic reconstructions for the Indian Ocean predict little or no relative motion between Australia and Broken Ridge from its construction by the Kerguelen hot spot in the middle Cretaceous until rifting in the middle Eocene (Luyendyk and Rennick, 1977; Royer and Sandwell, 1989). The Bunbury basalt (90 Ma) in western Australia gives an ill-constrained paleolatitude of $52^{\circ} \mathrm{S}$ (Schmidt, 1976). Accounting for the present latitudinal separation of Bunbury and Broken Ridge, this suggests a paleolatitude of approximately $49^{\circ} \mathrm{S}$ for the latter during the Late Cretaceous. Unfortunately, direct determinations of the Late Cretaceous paleolatitude of the Kerguelen-Heard platform are unavailable. Basement was not reached during Leg 121 drilling on Broken Ridge, and the limited basement penetration $(<50 \mathrm{~m})$ and possibility of tectonic rotations cast doubt on paleolatitudes from the Leg 120 basalts (Schlich, Wise, et al., 1989).

In spite of the lack of direct paleolatitudinal determinations, the tectonic models and land-based paleomagnetic data together suggest that Broken Ridge probably was at $47^{\circ}-50^{\circ} \mathrm{S}$ during deposition of the dipping and truncated sequence. Thus, the sediments below the Eocene angular unconformity constitute a 40 m.y. record of high-latitude sedimentation that should preserve a uniform inclination compatible with deposition within this range of paleolatitudes. With the exception of Hole 753A, however, the remaining holes have mean inclinations (Table 2 ) for which the confidence intervals do not overlap the expected $65^{\circ}-67^{\circ}$ inclination. The mean inclinations from Sites 752,754 , and 755 are from $5^{\circ}$ to $10^{\circ}$ too shallow.

\section{ORIGIN OF SHALLOW INCLINATIONS}

The shallow inclinations of the Broken Ridge sediments may be the result of several processes, including (1) relative motion between the hot spot and spin axis reference frames, (2) latitudinal displacement of Broken Ridge prior to rifting, (3) persistence of nondipole components in the time-averaged field, or (4) a bias inherent in the recording or preservation of the geomagnetic field in these sediments. The near coincidence of the tilt-corrected mean inclination for Hole $753 \mathrm{~A}\left(67.5^{\circ}\right)$ and the expected dipole inclination $\left(65^{\circ}-67^{\circ}\right)$ renders the first two explanations unlikely. Similarly, the $50^{\circ} \mathrm{S}$ basement paleolatitudes from Ninetyeast Ridge (Peirce, 1978; Klootwijk et al., this volume) constrain any prerift latitudinal motion of Broken Ridge or hot-spot drift to minimal values. Although the contribution of nondipole components cannot be discounted (e.g., Livermore et al., 1983; Schneider and Kent, 1988), the long (approximately 40 m.y.) duration of such an offset seems implausible.

Shallow inclinations in sediments may also result from either a depositional inclination error or subsequent shallowing from compaction. Depositional inclination errors are commonly noted in redeposition studies and have been attributed to the preferential alignment of platy minerals or the rolling of spherical particles into local depressions during deposition (e.g., King, 1955; Griffiths et al., 1960; Tauxe and Kent, 1984). Analysis of deep-sea sediments from shallow cores, however, indicates that these sediments typically carry a postdepositional remanence (PDRM) that accurately reflects the ambient field (e.g., Opdyke, 1972; Opdyke and Henry, 1969). The mean inclination of sediments from Hole $753 \mathrm{~A}$ agrees well with the predicted dipole inclination, effectively eliminating the possibility of a depositional inclination error in the Broken Ridge sediments. Although the initial PDRM generally exhibits no inclination error, experimental studies indicate that subsequent volume reduction may produce shallow inclinations (Anson and Kodama, 1987; Deamer and Kodama, 1990). Inclination shallowing has been noted in natural, clay-rich sediments (Kent and Spariosu, 1982; Arason and Levi, 1990a) as well as in carbonates (e.g., Tauxe et al., 1984; Celaya and Clement, 1988; Tarduno, 1990).

Comparison of inclination and porosity changes with depth suggests the importance of compaction-related inclination error in the sediments from Broken Ridge. In Figure 10 we plot mean inclinations and porosity values calculated for successive $40-\mathrm{m}$ intervals (Table 3). Composite depth is relative to the Eocene unconformity at Hole $753 \mathrm{~A}$, assuming a stratigraphic gap of 190 $\mathrm{m}$ between Holes 753A and 752A, an overlap of $20 \mathrm{~m}$ between Holes 752B and 754B, and a 490-m gap from Hole 754B to the uppermost sediments of Hole 755A. Mean inclination values decrease in the interval from 200 to $400 \mathrm{~m}$ composite depth and thereafter remain $5^{\circ}-10^{\circ}$ too shallow. This downcore variation in inclination is parallelled by changes in porosity, which we adopt as an indicator of compaction and lithification. The marked drop in porosity at a depth of approximately $400 \mathrm{~m}$ delineates an abrupt (20-m interval) diagenetic front that is reflected in a host of physical properties as well as in the downcore appearance of opal-CT (Peirce, Weissel, et al., 1989). Below $400 \mathrm{~m}$ composite depth, porosities are relatively constant, at approximately $30 \%$, 

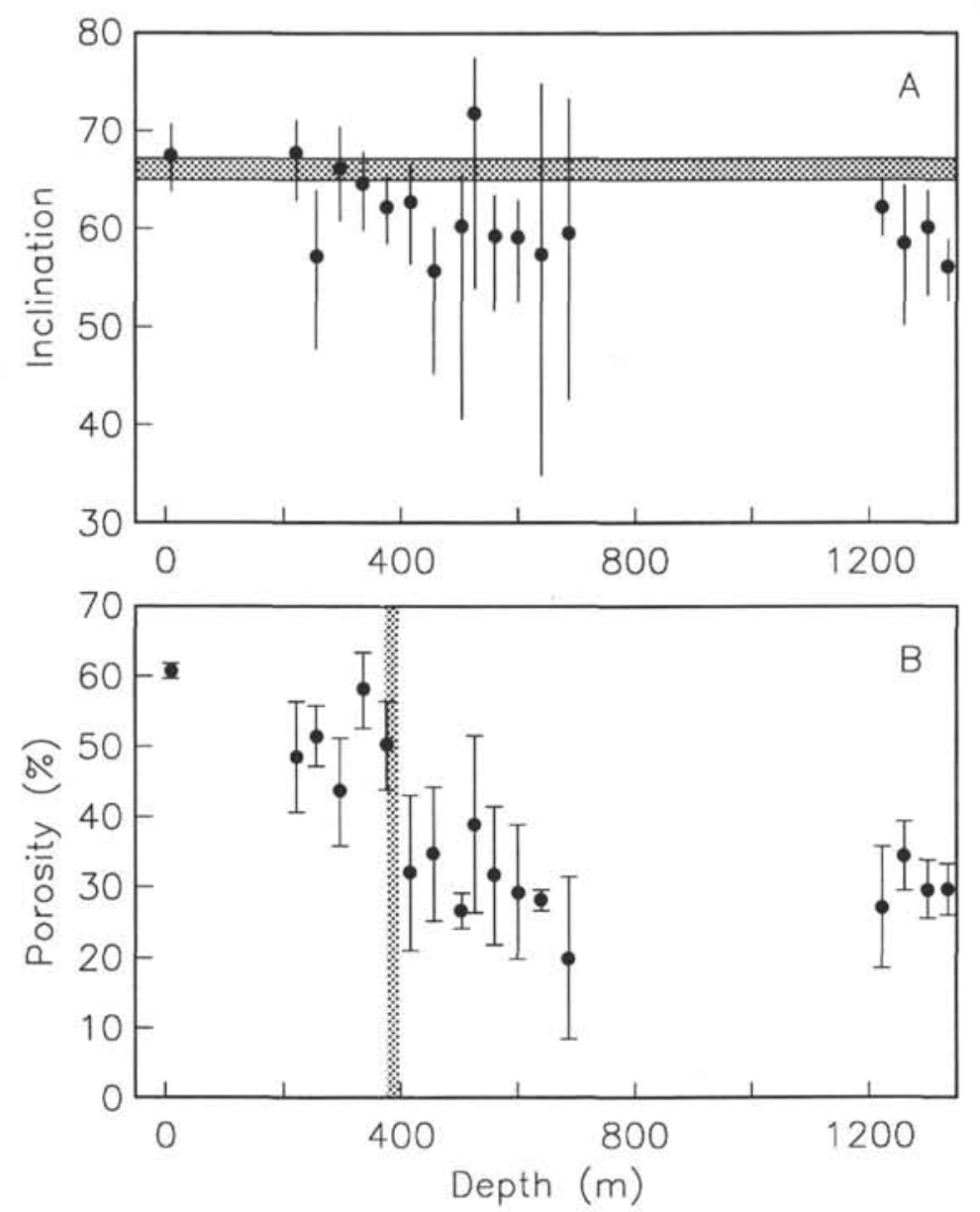

Figure 10. Variation in mean dip-corrected inclination (A) and porosity $(\mathbf{B})$ values for 40-m intervals as a function of composite depth. Data from Table 3. The dotted horizontal interval in Figure 10A indicates the range of expected Cretaceous/Paleogene inclinations at Broken Ridge inferred from tectonic models for the Indian Ocean and relevant land-based paleomagnetic data. The deviation of the inclination values from the expected value of $65^{\circ}-67^{\circ}$ is parallelled by a decrease in porosity with depth, suggesting the importance of compaction in generating the shallow inclinations. The dotted vertical interval in Figure 10B delineates a diagenetic front that occurs abruptly at $280-300 \mathrm{mbsf}$ in Hole $752 \mathrm{~B}$.

suggesting that the porosity profile was essentially established prior to uplift and is not a function of the present burial depth. The lack of further porosity reduction and pore-water data from the overlying sediments indicate that the diagenetic processes in the lower part of the section (Holes 754B and 755A) are essentially complete. The similarity between the inclination and porosity profiles (Fig. 10) strongly suggests compaction is a major factor in the observed shallow inclinations.

Anisotropy of ARM allows a quantitative evaluation of the possible role of compaction in generating shallow inclinations. The anisotropy of ARM has proven useful in determining the magnetic fabric of sediments, and, in contrast to the anisotropy of magnetic susceptibility, is restricted to the remanence-carrying fraction (e.g., McCabe et al., 1985). Anisotropy of ARM was determined for 13 samples spanning the 1350-m dipping and prerift sequence (Table 4 ). The shape of the anisotropy ellipsoid is classified as spherical if the maximum $\left(K_{l}\right)$, intermediate $\left(K_{2}\right)$, and minimum $\left(K_{3}\right)$ axes are statistically indistinguishable, triaxial if $K_{1}>K_{2}>K_{3}$, and oblate if $K_{1}=K_{2}>K_{3}$. Comparison of the principal axis lengths was made using the $t$ statistic and the standard deviation $(\sigma)$ derived from the bootstrapped confidence region. Two axes are statistically different if

$$
t_{12}=\frac{K_{1}-K_{2}}{\sqrt{\sigma_{1}^{2}+\sigma_{2}^{2}}}
$$

is greater than 2.353 , the critical value for three degrees of freedom at the $95 \%$ confidence level.

Based on these criteria, the majority of samples may be described by a triaxial anisotropy ellipsoid (Table 4). Two samples from the lower part of the section and a single sample from the base of Hole 752A are classified as oblate in shape. The predominance of triaxial ellipsoid shapes in the upper part of the section and the low percent anisotropy in the sample from Hole 753A suggest that postdepositional realignment results in a triaxial, or perhaps spherical, anisotropy ellipsoid. This is consistent with the observation that marine sediments typically have a postdepositional remanence that accurately records the geomagnetic field (e.g., Opdyke and Henry, 1969). Although only three samples are properly classified as oblate, there is a general trend of steepening inclination of the $K_{3}$ axis and increasing similarity in $K_{1}$ and $K_{2}$ 
Table 3. Interval inclination and porosity data.

\begin{tabular}{|c|c|c|c|c|c|c|c|c|c|c|}
\hline \multirow[b]{3}{*}{$\begin{array}{l}\text { Depth } \\
\text { (mbsf) }\end{array}$} & \multirow{3}{*}{$\begin{array}{c}\text { Composite } \\
\text { depth } \\
\text { (mbsf) }\end{array}$} & \multirow{2}{*}{\multicolumn{3}{|c|}{ Porosity data }} & \multicolumn{6}{|c|}{ Interval inclination data } \\
\hline & & & & & \multirow[b]{2}{*}{$n$} & \multirow{2}{*}{$\begin{array}{c}\text { Mean } \\
\text { inclination } \\
\text { (degrees) }\end{array}$} & \multicolumn{2}{|c|}{$\begin{array}{c}95 \% \\
\text { Confidence } \\
\text { interval }\end{array}$} & \multirow[b]{2}{*}{ Alpha } & \multirow[b]{2}{*}{ Kappa } \\
\hline & & $n$ & $(\%)$ & $\begin{array}{l}\text { Standard } \\
\text { deviation }\end{array}$ & & & Upper & Lower & & \\
\hline \multicolumn{11}{|l|}{ Hole 753A } \\
\hline $43.6-62.8$ & 9.6 & 6 & 60.74 & 1.1 & 9 & 67.5 & +3.2 & -3.7 & 3.4 & 236.5 \\
\hline \multicolumn{11}{|l|}{ Hole $752 \mathrm{~A}$} \\
\hline $\begin{array}{l}112.9-140.0 \\
140.0-180.0 \\
180.0-220.0 \\
220.0-260.0 \\
260.0-300.0\end{array}$ & $\begin{array}{l}222.8 \\
256.3 \\
296.3 \\
336.3 \\
376.3\end{array}$ & $\begin{array}{r}11 \\
12 \\
8 \\
8 \\
8 \\
14\end{array}$ & $\begin{array}{l}48.52 \\
51.55 \\
43.57 \\
58.04 \\
50.16\end{array}$ & $\begin{array}{l}7.9 \\
4.3 \\
7.7 \\
5.4 \\
6.3\end{array}$ & $\begin{array}{r}15 \\
12 \\
8 \\
17 \\
18 \\
18\end{array}$ & $\begin{array}{l}67.8 \\
57.3 \\
66.1 \\
64.6 \\
62.4\end{array}$ & $\begin{array}{l}+3.3 \\
+6.7 \\
+4.5 \\
+3.3 \\
+2.9\end{array}$ & $\begin{array}{l}-4.9 \\
-9.5 \\
-5.3 \\
-4.8 \\
-3.9\end{array}$ & $\begin{array}{l}4.1 \\
8.1 \\
4.9 \\
4.0 \\
3.4\end{array}$ & $\begin{array}{r}86.0 \\
29.2 \\
138.0 \\
76.6 \\
99.0\end{array}$ \\
\hline \multicolumn{11}{|l|}{ Hole 752B } \\
\hline $\begin{array}{l}300.0-340.0 \\
340.0-380.0 \\
380.0-435.6\end{array}$ & $\begin{array}{l}416.3 \\
456.3 \\
504.1\end{array}$ & $\begin{array}{r}13 \\
8 \\
10\end{array}$ & $\begin{array}{l}32.08 \\
34.75 \\
26.70\end{array}$ & $\begin{array}{r}11.0 \\
9.5 \\
2.5\end{array}$ & $\begin{array}{l}19 \\
29 \\
29\end{array}$ & $\begin{array}{l}62.8 \\
55.7 \\
60.5\end{array}$ & $\begin{array}{l}+3.9 \\
+4.5 \\
+4.9\end{array}$ & $\begin{array}{r}-6.4 \\
-10.5 \\
-19.9\end{array}$ & $\begin{array}{r}5.1 \\
7.5 \\
12.4\end{array}$ & $\begin{array}{r}42.0 \\
14.0 \\
7.0\end{array}$ \\
\hline \multicolumn{11}{|l|}{ Hole 754B } \\
\hline $\begin{array}{l}151.7-180.0 \\
180.0-220.0 \\
220.0-260.0 \\
260.0-300.0 \\
300.0-354.7\end{array}$ & $\begin{array}{l}526.1 \\
560.2 \\
600.2 \\
640.2 \\
687.6\end{array}$ & $\begin{array}{r}15 \\
8 \\
11 \\
4 \\
6\end{array}$ & $\begin{array}{l}39.00 \\
31.69 \\
29.40 \\
28.19 \\
19.99\end{array}$ & $\begin{array}{r}12.6 \\
9.8 \\
9.5 \\
1.5 \\
11.5\end{array}$ & $\begin{array}{r}15 \\
21 \\
26 \\
6 \\
6\end{array}$ & $\begin{array}{l}71.6 \\
59.2 \\
59.4 \\
57.5 \\
59.7\end{array}$ & $\begin{array}{r}+5.8 \\
+4.3 \\
+3.6 \\
+17.3 \\
+13.6\end{array}$ & $\begin{array}{r}-17.7 \\
-7.5 \\
-6.8 \\
-22.6 \\
-17.1\end{array}$ & $\begin{array}{r}10.9 \\
5.9 \\
5.2 \\
20.0 \\
15.4\end{array}$ & $\begin{array}{l}14.9 \\
29.2 \\
29.9 \\
14.6 \\
24.0\end{array}$ \\
\hline \multicolumn{11}{|l|}{ Hole 755A } \\
\hline $\begin{array}{r}65.2-100.0 \\
100.0-140.0 \\
140.0-180.0 \\
180.0-208.4\end{array}$ & $\begin{array}{l}1222.3 \\
1259.7 \\
1299.7 \\
1333.9\end{array}$ & $\begin{array}{r}6 \\
7 \\
11 \\
7\end{array}$ & \begin{tabular}{l|l}
27.18 \\
34.44 \\
29.68 \\
29.64
\end{tabular} & $\begin{array}{l}8.6 \\
4.9 \\
4.1 \\
3.6\end{array}$ & $\begin{array}{l}12 \\
12 \\
24 \\
22\end{array}$ & $\begin{array}{l}62.3 \\
58.5 \\
60.1 \\
56.2\end{array}$ & $\begin{array}{l}+2.7 \\
+6.0 \\
+3.8 \\
+2.7\end{array}$ & $\begin{array}{l}-3.1 \\
-8.3 \\
-6.9 \\
-3.6\end{array}$ & $\begin{array}{l}2.9 \\
7.2 \\
5.3 \\
3.1\end{array}$ & $\begin{array}{r}221.5 \\
37.2 \\
30.8 \\
90.0\end{array}$ \\
\hline
\end{tabular}

Note: Inclination conventions as in Table 2.

Table 4. Summary of anisotropy of anhysteretic remanence.

\begin{tabular}{|c|c|c|c|c|c|c|c|c|}
\hline \multirow{2}{*}{$\begin{array}{l}\text { Depth } \\
\text { (mbsf) }\end{array}$} & \multirow{2}{*}{$\begin{array}{c}\text { Composite } \\
\text { depth }^{\mathrm{a}} \\
\text { (mbsf) }\end{array}$} & \multirow{2}{*}{$\begin{array}{c}\text { Sample } \\
\text { (interval in } \mathrm{cm} \text { ) }\end{array}$} & \multirow{2}{*}{$\begin{array}{c}\text { Percent } \\
\text { anisotropy }\end{array}$} & \multicolumn{2}{|c|}{$t$ statistic $^{\mathrm{c}}$} & \multirow[b]{2}{*}{ Shape } & \multirow{2}{*}{$\begin{array}{c}K_{3} \\
\text { inclination } \\
\text { (degrees) }\end{array}$} & \multirow{2}{*}{$\begin{array}{c}F \\
\left(K_{2} / K_{3}\right)\end{array}$} \\
\hline & & & & $t_{12}$ & $t_{23}$ & & & \\
\hline 48.7 & 5.1 & $753 \mathrm{~A}-6 \mathrm{H}-4,63$ & 1.63 & 3.054 & 4.953 & Triaxial & 43.0 & 1.030 \\
\hline 138.0 & 234.3 & $752 \mathrm{~A}-15 \mathrm{X}-4,123$ & 3.63 & 2.620 & 3.959 & Triaxial & 61.1 & 1.063 \\
\hline 181.7 & 278.0 & $752 \mathrm{~A}-20 \mathrm{X}-1,100$ & 3.48 & 2.950 & 6.682 & Triaxial & 68.8 & 1.072 \\
\hline 221.2 & 317.5 & $752 A-24 X-2,64$ & 7.65 & 3.640 & 2.875 & Triaxial & 56.7 & 1.099 \\
\hline 278.6 & 374.9 & $752 \mathrm{~A}-30 \mathrm{X}-1,123$ & 5.01 & 1.632 & 7.357 & Oblate & 62.1 & 1.124 \\
\hline 319.4 & 415.7 & $752 \mathrm{~B}-7 \mathrm{R}-3,32$ & 5.98 & 3.396 & 40.357 & Triaxial & 84.1 & 1.184 \\
\hline 404.1 & 500.4 & 752B-16R-1, 107 & 3.95 & 4.037 & 22.458 & Triaxial & 81.2 & 1.105 \\
\hline 405.5 & 501.8 & 752B-16R-2, 97 & 6.18 & 3.730 & 41.699 & Triaxial & 85.5 & 1.188 \\
\hline 155.8 & 516.0 & $754 \mathrm{~B}-5 \mathrm{R}-3,109$ & 3.23 & 4.059 & 33.489 & Triaxial & 83.5 & 1.086 \\
\hline 249.5 & 609.7 & $754 \mathrm{~B}-15 \mathrm{R}-1,132$ & 6.22 & 3.165 & 54.696 & Triaxial & 84.7 & 1.195 \\
\hline 297.5 & 657.7 & 754B-20R-1, 79 & 2.37 & 1.704 & 4.927 & Oblate & 63.4 & 1.054 \\
\hline 82.8 & 1222.5 & 755A-7R-1, 102 & 4.27 & 3.078 & 8.463 & Triaxial & 70.4 & 1.092 \\
\hline 202.9 & 1342.6 & $755 \mathrm{~A}-19 \mathrm{R}-3,122$ & 6.87 & 1.208 & 11.857 & Oblate & 78.9 & 1.215 \\
\hline
\end{tabular}

${ }^{\text {a }}$ Relative to unconformity at Hole 753A; calculated assuming a 190-m gap between the base of Hole 753A and the top of Hole 752A, 20-m overlap between the base of Hole 752B and the top of Hole 754B, and a 490-m gap between the base of Hole 754B and the top of Hole 755A.

b $100 \times\left(K_{1}-K_{3}\right) /\left(K_{1}+K_{2}+K_{3}\right)$.

${ }^{\mathrm{c}}$ For comparison of eigenvalues. Critical value for $n=4$, three degrees of freedom, is 2.353 .

with depth. Figure 11 illustrates the range of triaxial ellipsoid shapes. The ratio of $K_{2} / K_{3}(F)$ provides a quantitative estimate of this flattening (Table 4). Although $F$ and the inclination of $K_{3}$ do not increase monotonically with depth, the general trend toward higher values at composite depths $>400 \mathrm{~m}$ is evident in Figure 12. These general trends, together with the occurrence of oblate ellipsoids at the base of the section, provide additional support for the importance of compaction-related inclination shallowing in sediments from Broken Ridge.

The anomalously shallow inclinations observed in sediments from Broken Ridge compare favorably with experimentally derived expressions for inclination error. Inclination error is a function of the initial inclination, with the maximum effect at initial inclinations of $40^{\circ}-60^{\circ}$ and inclination error decreasing toward 


$$
121-753 a-6 h-4,63 c m
$$

A
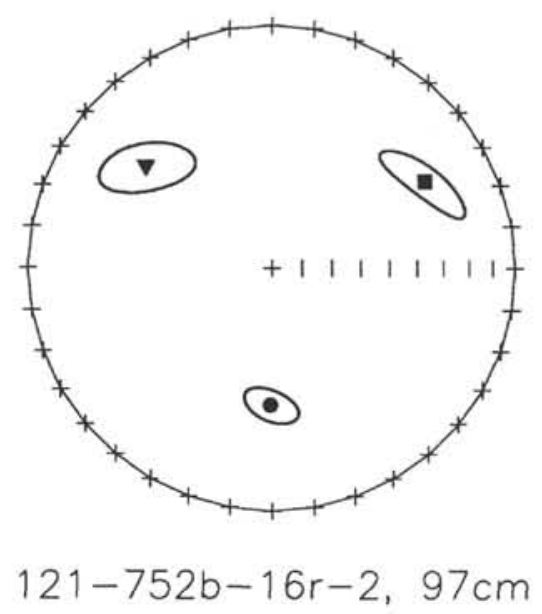

- Kmax

Vint

- Kmin

B

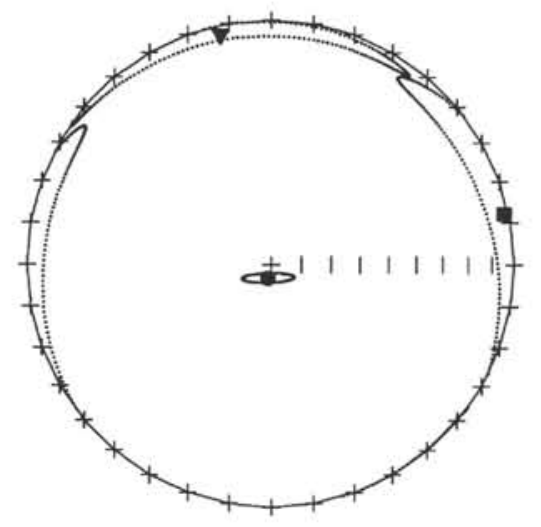

Figure 11. Anisotropy of anhysteretic remanence measured for two samples from the upper (A) and lower (B) portions of the prerift sediment sequence. Although both anisotropy ellipsoids are classified as triaxial, the inclination of the minimum axis steepens and the difference between the maximum and intermediate axes decreases with increasing depth.

initial inclinations near $90^{\circ}$ and near $0^{\circ}$ (e.g., King, 1955). Thus, the steep expected inclination $\left(67^{\circ}\right)$ at Broken Ridge is compatible with a large inclination error. Experimental and theoretical studies suggest that the inclination error is related to the reduction in volume by

$$
\tan \left(I_{r}\right)=(1-a \Delta v) \tan \left(I_{0}\right),
$$

where $I_{r}$ is the inclination measured after compaction, $I_{0}$ is the initial inclination, $\Delta v$ is the percent volume reduction, and $a$ is an experimentally derived constant (Anson and Kodama, 1987; Arason and Levi, $1990 \mathrm{~b})$. The volume reduction is related to the porosity $(\phi)$ and the initial porosity $\left(\phi_{0}\right)$ by

$$
\Delta v=\frac{\left(\phi_{0}-\phi\right)}{(1-\phi)} .
$$

Anson and Kodama (1987) reported values of $0.54 \pm 0.18$ and $0.63 \pm 0.18$ for the parameter $a$ for equidimensional and acicular magnetite in synthetic kaolinite sediments. The data from the basal portion of the Broken Ridge section provide an estimate of this parameter which is applicable to well-lithified, carbonate-rich sediments. We assume an initial inclination of $67^{\circ}$ and an initial porosity of $72 \%$, consistent with the measured porosity values in the pelagic carbonates on Broken Ridge (Pierce, Weissel, et al.,
1989). The data for Site 755 in Table 3 indicate volume reductions of 0.57 to 0.62 (neglecting the effect of cementation) and yield an average value of $a=0.47$. The sediments from Holes 754B and $752 \mathrm{~B}$ give comparable results, all of which are close to the value derived from the experimental data of Anson and Kodama (1987).

The expression for compaction-related inclination shallowing also indicates that the nearly horizontal inclinations observed in some samples from Broken Ridge cannot be explained by this mechanism. For example, generating inclinations $<10^{\circ}$ by this mechanism (assuming 30\% final porosity) requires $a$ values $>1.5$, far in excess of the observed values. Although Arason and Levi (1990a) have reported high values of $a$ (up to 4) in carbonates, these values were derived from relatively short sections with little volume change and are clearly not applicable to more consolidated carbonates. Electrostatic or Van der Waals attraction between magnetite and clay particles (Anson and Kodama, 1987; Deamer and Kodama, 1990) might produce nearly horizontal inclinations for the smaller grain-size fractions (equivalent to a higher value of $a$ ). The high coercivity range of some of the horizontal components in the Broken Ridge sediments appears to support this mechanism; however, horizontal inclinations over significant blocking temperature or coercivity ranges (e.g., Fig. $3 \mathrm{G})$ are difficult to explain by this mechanism. We suggest that these very shallow inclinations may result from superposed components of opposite polarity and similar magnitude. Provided the coercivity or blocking temperature spectra of these components are similar, this mechanism can account for nearly horizontal characteristic magnetizations.

\section{CONCLUSIONS}

The dipping and truncated Paleogene to Upper Cretaceous sequence from Broken Ridge records approximately 40 m.y. of sedimentation at high southern latitudes. These sediments preserve a polarity sequence that extends from Chron C18/C20 (middle Eocene) to C34 (Upper Cretaceous) and includes a 500-m continuous section from C23R (lower Paleocene) to C32R (Maestrichtian/Campanian boundary). The continuity and high mass-accumulation rates of the Broken Ridge sediments provide an excellent opportunity to compare high-latitude austral assemblages both with the GRTS and standard low-latitude zonation schemes. Although tectonic reconstructions for the Indian Ocean suggest that the prerift sediments on Broken Ridge should exhibit an inclination consistent with deposition at approximately $47^{\circ}$ $50^{\circ} \mathrm{S}$, the observed inclinations are up to $10^{\circ}$ too shallow. The covariance of porosity and inclination data downcore strongly suggests compaction is the controlling factor in generating these shallow inclinations. Anisotropy of anhysteretic remanence studies provide additional support for this interpretation.

\section{ACKNOWLEDGMENTS}

We thank Rachel Friedman for assisting with sample measurements. Funds for the Scripps Paleomagnetic Laboratory are kindly provided by the Keck Foundation. Support for this project was provided by a USSAC grant and through NSF Grant OCE9000182. C. T. Klootwijk publishes with the permission of the Director, Bureau of Mineral Resources.

\section{REFERENCES}

Alvarez, W., and Lowrie, W., 1978. Upper Cretaceous palaeomagnetic stratigraphy at Moria (Umbrian Apennines, Italy): verification of the Gubbio section. Geophys. J. R. Astron. Soc., 55:1-17.

Anson, G. L., and Kodama, K. P., 1987. The effects of compaction on a synthetic PDRM. Geophys. J. R. Astron. Soc., 88:673-692.

Arason, P., and Levi, S., 1990a. Compaction and inclination shallowing in deep-sea sediments from the Pacific Ocean. J. Geophys. Res., 95:4501-4510. 
1990b. Models of inclination shallowing during sediment compaction. J. Geophys. Res., 95:4481-4500.

Baksi, A. K., 1986. ${ }^{40} \mathrm{Ar}-{ }^{39} \mathrm{Ar}$ incremental heating study of whole rock samples from the Rajmahal and Bengal Traps, eastern India. Terra Cogn., 6:161. (Abstract)

Barron, J., Larsen, B., et al., 1989. Proc. ODP, Init. Repts., 119: College Station, TX (Ocean Drilling Program).

Berggren, W. A., Kent, D. V., Flynn, J. J., and Van Couvering, J. A., 1985. Cenozoic geochronology. Geol. Soc. Am. Bull., 96:1407-1418.

Bolli, H. M., Saunders, J. B., and Perch-Nielsen, K. (Eds.), 1985. Plankton Stratigraphy: Cambridge (Cambridge Univ. Press).

Celaya, M. A., and Clement, B. M., 1988. Inclination shallowing in deep sea sediments from the North Atlantic. Geophys. Res. Lett., 15:52-55.

Constable, C. G., and Tauxe, L., 1990. The bootstrap for magnetic susceptibility tensors. J. Geophys. Res., 95:8383-8395.

Deamer, G. A., and Kodama, K. P., 1990. Compaction-induced inclination shallowing in synthetic and natural clay-rich sediments. J. Geophys. Res., 95:4511-4530.

Griffiths, D. H., King, R. F., Rees, A. I., and Wright, A. E., 1960. Remanent magnetism of some recent varved sediments. Proc. R. Soc. London A, 256:359-833.

Kent, D. V., and Gradstein, F. M., 1985. A Cretaceous and Jurassic geochronology. Geol. Soc. Am. Bull., 96:1419-1427.

Kent, D. V., and Spariosu, D., 1982. Magnetostratigraphy of Caribbean Site 502 hydraulic piston cores. In Prell, W. L., Gardner, J. V., et al., Init. Repts. DSDP, 68: Washington (U.S. Govt. Printing Office), 419-434.

King, R. F., 1955. The remanent magnetism of artificially deposited sediments. Mon. Not. R. Astron. Soc., Geophys. Suppl,, 7:115-134.

Kirschvink, J. L., 1980. The least-squares line and plane analysis of palaeomagnetic data. Geophys. J. R. Astron. Soc., 62:699-718.

Klootwijk, C. T., 1971. Palaeomagnetism of the Upper Gondwana Rajmahal Traps, northeast India. Tectonophysics, 12:449-467.

Livermore, R. A., Vine, F. J., and Smith, A. G., 1983. Plate motions and the geomagnetic field. I. Quaternary and late Tertiary. Geophys. J. R. Astron. Soc., 73:153-171.

Lowrie, W., and Alvarez, W., 1977. Upper Cretaceous-Paleocene magnetic stratigraphy at Gubbio, Italy. III. Upper Cretaceous magnetic stratigraphy. Geol. Soc. Am. Bull., 88:374-377.

Lowrie, W., and Heller, F., 1982. Magnetic properties of marine limestones. Rev. Geophys. Space Phys., 20:171-192.

Luyendyk, B. P., and Rennick, W., 1977. Tectonic history of aseismic ridges in the eastern Indian Ocean. Geol. Soc. Am. Bull., 88:13471356.

McCabe, C., Jackson, M., and Ellwood, B. B., 1985. Magnetic anisotropy in the Trenton limestone: results of a new technique, anisotropy of anhysteretic susceptibility. Geophys. Res. Lett., 12:333-336.
McFadden, P. L., and Reid, A. B., 1982. Analysis of paleomagnetic inclination data. Geophys. J. R. Astron. Soc., 69:307-319.

Miller, S. P., 1977. The validity of the geological interpretations of marine magnetic anomalies. Geophys. J. R. Astron. Soc., 50:1-21.

Mutter, J. C., and Cande, S. C., 1983. The early opening between Broken Ridge and Kerguelen Plateau. Earth Planet. Sci. Lett., 65:369-376.

Opdyke, N. D., 1972. Paleomagnetism of deep-sea cores. Rev. Geophys. Space Phys., 10:213-249.

Opdyke, N. D., and Henry, K. W., 1969. A test of the dipole hypothesis. Earth Planet. Sci. Lett., 6:138-151.

Peirce, J., Weissel, J., et al., 1989. Proc. ODP, Init. Repts., 121: College Station, TX (Ocean Drilling Program).

Peirce, J. W., 1978. The northward motion of India since the Late Cretaceous. Geophys. J.R. Astron. Soc., 52:277-311.

Rea, D. K., Dehn, J., Driscoll, N., Farrell, J., Janecek, T., Owen, R. M., Pospichal, J. L., Resiwati, P., and the ODP Leg 121 Scientific Party, 1990. Paleoceanography of the eastern Indian Ocean from ODP Leg 121 drilling on Broken Ridge. Geol. Soc. Am. Bull., 102:679-690.

Royer, J. Y., and Sandwell, D. T., 1989. Evolution of the eastern Indian Ocean since the Late Cretaceous: constraints from GEOSAT altimetry. J. Geophys. Res., 94:13755-13782.

Schlich, R., Wise, S. W., Jr., et al., 1989. Proc. ODP, Init Repts., 120: College Station, TX (Ocean Drilling Program).

Schmidt, P. W., 1976. A new paleomagnetic investigation of Mesozoic igneous rocks in Australia. Tectonophysics, 33:1-13.

Schneider, D. A., and Kent, D. V., 1988. Inclination anomalies from Indian Ocean sediments and the possibility of a standing non-dipole field. J. Geophys. Res., 93:11621-11630.

Sissingh, W., 1977. Biostratigraphy of Cretaceous calcareous nannoplankton. Geol. Mijnbouw, 56:37-65.

Tarduno, J. A., 1990. Absolute inclination values from deep sea sediments: a reexamination of the Cretaceous Pacific record. Geophys. Res. Lett., 17:101-104.

Tauxe, L., and Kent, D. V., 1984. Properties of a detrital remanence carried by haematite from study of modern river deposits and laboratory redeposition experiment. Geophys. J. R. Astron. Soc., 77:543561

Tauxe, L., Tucker, P., Petersen, N. P., and LaBrecque, J. L., 1984. Magnetostratigraphy of Leg 73 sediments. In Hsü, K. J., LaBrecque, J. L., et al., Init. Repts. DSDP, 73: Washington (U.S. Govt. Printing Office), 609-621.

Date of initial receipt: 13 April 1990

Date of acceptance: 25 October 1990 Ms 121B-151 


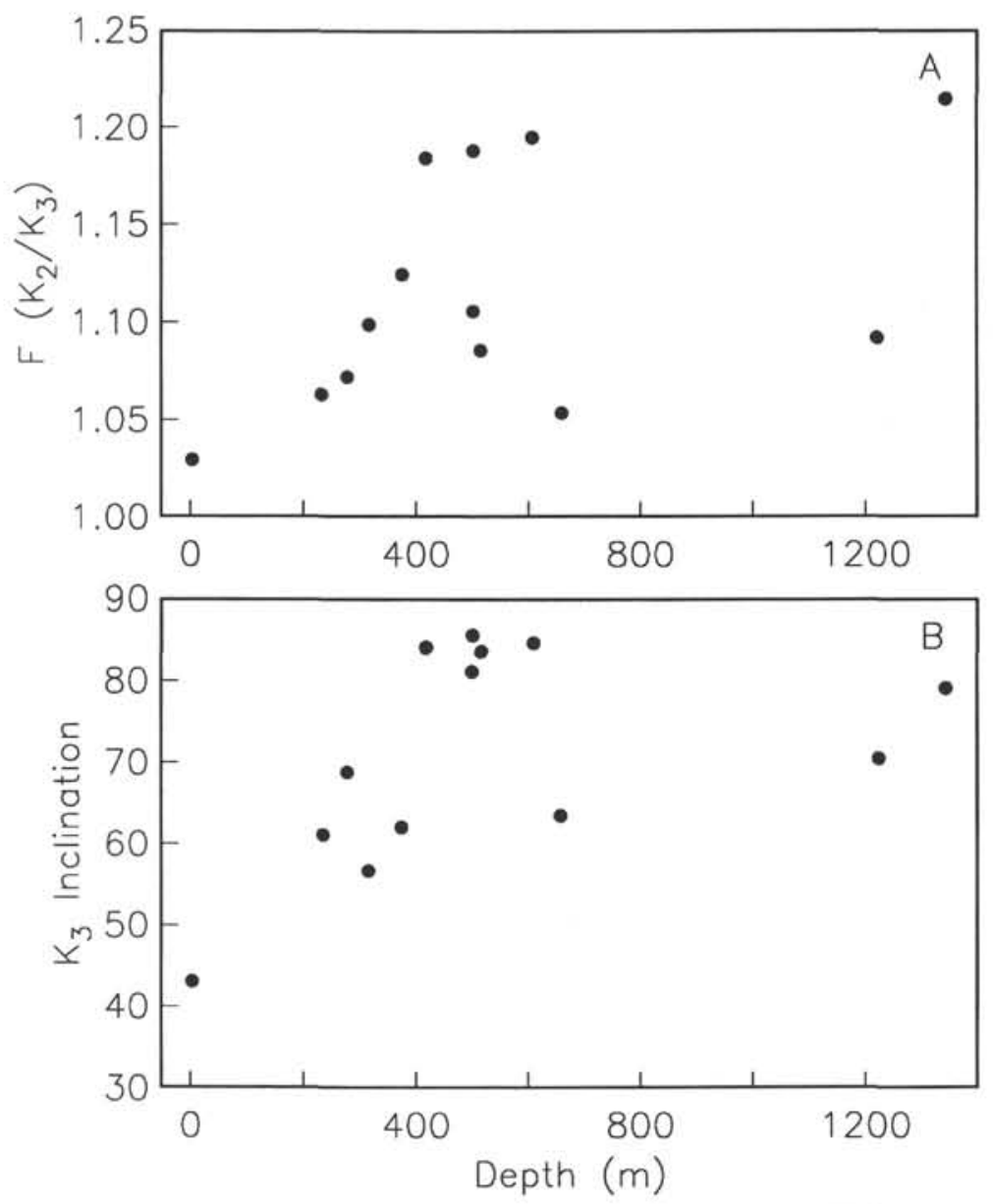

Figure 12. Variation in the flatness $\left(F=K_{2} / K_{3}\right)$ of the anisotropy ellipsoid (A) and the inclination of the $K_{3}$ axis (B) with depth. Although neither parameter increases monotonically with depth, the general trend toward higher values below a composite depth of $400 \mathrm{~m}$ is evident. 